\title{
ANTHROPOLOGICAL COMPOSITION OF THE POPULATION OF THE EARLY IRON AGE FROM THE LOWER VOLGA REGION (ACCORDING TO THE MATERIALS OF THE KURGAN GROUP OF KRIVAYA LUKA) ${ }^{1}$
}

\author{
Mariya A. Balabanova \\ Volgograd State University, Volgograd, Russian Federation
}

\begin{abstract}
The article is devoted to the craniological materials of the early Iron Age from the kurgans of Krivaya Luka tract in the Astrakhan region, which were excavated during ten field seasons. The rich anthropological material was obtained as a result of the excavations studied by A.V. Shevchenko, A.A. Kazarnitskiy, M.A. Balabanova, L.T. Yablonskiy. The anthropological materials of the Early Iron Age consisted of 85 skulls are studied in the current article using the traditional method of simple and multivariate statistics. As a result of the study, it was found out that the morphological appearance of cultural-chronological groups is similar to the rest of the synchronous population both from other burials grounds of the Lower Volga region and from adjacent territories. The Sarmatian type or the type of the ancient Eastern Caucasian is inherent for a small group of the pre-Savromatian period, as well as for the groups of the Savromatian and Early Sarmatian period. A small Middle Sarmatian male group demonstrates the combinations that characterize the subsequent Late Sarmatian population - the type of long-headed Caucasians. Whereas the female craniological type of the Late Sarmatian time is characterized by a set of features that define it as a Mongoloid-Caucasian mestizo. Both the total group of skulls and individual cultural-chronological groups turned out to be heterogeneous in terms of the intragroup structure. The anthropological type of the Early Iron Age population who left burials in the Krivaya Luka tract demonstrates diachronic variability, which was apparently associated with migrations. However, in the pre-Savromatian period, in comparison with the Late Bronze Age, this territory was occupied mostly by the type of ancient Eastern Caucasians which combines a mesobrachicranial lowvaulted cerebral box with a wide face, the horizontal profiling of which at the upper level is weakened, and the nose protruding sharply towards the profile line. The latter type remained there until the start of the Common era, and starting from the Middle Sarmatian time it changed to the type of long-headed Caucasians, which is associated with the penetration of alien groups. Among these migrants, apparently, there were also found carriers of the mixed Mongoloid-Caucasian complex.
\end{abstract}

Key words: kurgans of Krivaya Luka tract, Savromats, Sarmatians, anthropological type, statistical methods, ethno genetic relationships, intragroup structure.

Citation. Balabanova M.A., 2020. Antropologicheskiy sostav naseleniya rannego zheleznogo veka Nizhnego Povolzh'ya (po materialam kurgannyh grupp Krivoy Luki) [Anthropological Composition of the Population of the Early Iron Age from the Lower Volga Region (According to the Materials of the Kurgan Group of Krivaya Luka)]. Nizhnevolzhskiy Arkheologicheskiy Vestnik [The Lower Volga Archaeological Bulletin], vol. 19, no. 2, pp. 18-55. DOI: https://doi.org/10.15688/nav.jvolsu.2020.2.2 


\title{
АНТРОПОЛОГИЧЕСКИЙ СОСТАВ НАСЕЛЕНИЯ РАННЕГО ЖЕЛЕЗНОГО ВЕКА НИЖНЕГО ПОВОЛЖЬЯ (ПО МАТЕРИАЛАМ КУРГАННЫХ ГРУПП КРИВОЙ ЛУКИ) ${ }^{1}$
}

\author{
Мария Афанасьевна Балабанова \\ Волгоградский государственный университет, г. Волгоград, Российская Федерация
}

\begin{abstract}
Аннотация. В статье изучаются краниологические материалы эпохи раннего железного века из могильников урочища Кривая Лука в Астраханской области, которые раскапывались в течение десяти полевых сезонов. Богатый антропологический материал, полученный в результате раскопок, изучался А.В. Шевченко, А.А. Казарницким, М.А. Балабановой, Л.Т. Яблонским. В данной работе антропологические материалы раннего железного века численностью 85 черепов изучаются по традиционной методике простой и многомерной статистики. В результате исследования удалось выяснить, что морфологический облик культурнохронологических групп схож с остальным синхронным населением как из других могильников Нижнего Поволжья, так и из сопредельных территорий. Для небольшой группы предсавроматского времени, как и для групп савроматского и раннесарматского времени, характерен сарматский тип, или тип древних восточных европеоидов. Небольшая среднесарматская мужская группа демонстрирует сочетания, которые характеризуют последующее позднесарматское население - тип длинноголовых европеоидов. Женский краниологический тип позднесарматского времени характеризуется набором признаков, определяющих его как монголоидно-европеоидных метисов. Как суммарная группа черепов, так и отдельные культурно-хронологические группы оказались по внутригрупповой структуре неоднородными. Антропологический тип населения раннего железного века, оставившего могильники в урочище Кривая Лука, демонстрирует диахронную изменчивость, которая, видимо, была связана с миграциями. Уже в предсавроматское время, по сравнению с поздней бронзой, на этой территории большой вес приобретает тип древних восточных европеоидов, который сочетает мезобрахикранную низкосводчатую мозговую коробку с широким лицом, горизонтальная профилировка которого на верхнем уровне ослаблена, а нос - резко выступающий к линии профиля. Он продержался здесь до рубежа эр, а начиная со среднесарматского времени меняется на тип длинноголовых европеоидов, который связан с проникновением пришлых групп. Среди этих мигрантов, видимо, были и носители смешанного монголоидно-европеоидного комплекса.
\end{abstract}

Ключевые слова: могильники в урочище Кривая Лука, савроматы, сарматы, антропологический тип, статистические методы, этногенетические связи, внутригрупповая структура.

Цитирование. Балабанова М. А., 2020. Антропологический состав населения раннего железного века Нижнего Поволжья (по материалам курганных групп Кривой Луки) // Нижневолжский археологический вестник. Т. 19, № 2. С. 18-55. DOI: https://doi.org/10.15688/nav.jvolsu.2020.2.2

Введение. Антропологические материалы, которые публикуются в данной статье, были получены в процессе раскопок могильников в урочище Кривая Лука Поволжской археологической экспедицией с 1973 по 1981 год. Работы проводились в связи с мелиоративными мероприятиями в зоне строительства первой очереди Астрахано-Калмыцкой рисовой оросительной системы. До раскопок курганные группы располагались с севера на юг в 60-километровой зоне высохшего русла Волги, получившего название «урочище Кривая Лука» [Дворниченко и др., 1977, с. 3]. В течение десяти полевых сезонов было раскопано около трех с половиной сотен курганов. Для более комплексного изучения материалов раскопок наряду с археологами в экспедиции участвовали антропологи, остеологи, почвоведы. Результаты раскопок дали богатый археологический материал, и только данные по первым шести курганным группам были опубликованы [Дворниченко и др., 1977]. Часть материала введена в научный оборот в виде отдельных публикаций [Федоров-Давыдов, 1984; Дворниченко, Федоров-Давыдов, 1989; Круглов, 2001; Мимоход, 2005; 2014; 2019; Дворниченко, Демиденко, 2017]. 
Антропологические материалы, которые были получены при раскопках могильников Кривой Луки и собраны Л.Т. Яблонским, участвовавшим в экспедиции, изучены в большей степени, чем археологические. По мнению этого ученного, благодаря исследованиям материалов Кривой Луки Нижнее Поволжье в палеоантропологическом отношении стало одним из наиболее исследованных регионов России [Яблонский, 2002, с. 29].

Так, довольно значительные краниологические материалы эпохи бронзы были использованы А.В. Шевченко при написании диссертации на соискание степени кандидата исторических наук [Шевченко, 1980], а позднее опубликованы в работе 1986 года. Определяя антропологический тип серии ямной культуры Кривой Луки, он отмечает сходство ее с суммарной серией из Калмыкии и выделенного им типа А, который был одним из компонентов внутригрупповой структуры данного населения. Различия же между этими группами связаны с такими признаками, как более низкая высота свода черепа и лица и «крайне резкое выступание носа» у ямников Кривой Луки. Кроме того, автор отмечает сходство диахронных групп ранних и поздних ямников Кривой Луки, а также участие в их расогенезе каких-то узколицых групп. Что касается серии ямно-катакомбного времени, которая у него фигурирует под IV группой погребений, то она, по мнению А.В. Шевченко, формировалась под влиянием населения северокавказского происхождения [Шевченко, 1986, с. 143, 144, 168-172].

Небольшая серия черепов без следов искусственной деформации катакомбной культуры из Кривой Луки отличается от группы из Калмыкии более крупными размерами мозговой коробки и широким лицом [Шевченко, 1986, c. 185].

Серию поздней бронзы из курганных групп Кривой Луки наряду с другими группами бассейна Волги этот исследователь определяет как модификацию длинноголового типа со среднешироким лицом и резко выступающим носом [Шевченко, 1986, с. 192-194].

Этот же краниологический материал позднее изучал А.А. Казарницкий [2012]. Проведенный им внутригрупповой анализ показал неоднородность мужской серии ямной куль- туры, которая состоит из двух морфологических вариантов. Различия у них между широтными размерами и углами профилировки лица на среднем уровне. Немногочисленная женская серия обладает более гомогенной внутригрупповой структурой и отличается от группы черепов из Чограя более длинной и более узкой мезокранной черепной коробкой. Лицевой скелет также более узкий и резче профилированный в горизонтальной плоскости, а переносье более широкое и менее высокое [Казарницкий, 2012, с. 59-66].

Согласно современным культурно-хронологическим определениям, среди материалов Кривой Луки эпохи поздней стадии средней бронзы были выделены погребения лолинской и криволукской культуры, черепа которых изучили А.А. Хохлов и А.А. Казарницкий [Хохлов, Мимоход, 2008; Казарницкий, 2010; 2012; 2013a; 2103б; 2020].

По мнению А.А. Казарницого, черепа из погребений лолинской культуры могильников Кривая Лука отличаются низким лицом и очень низкими орбитами [Казарницкий, 2012, c. 113,114$]$. Отдельное исследование по посткатакомбным культурам показало, что на фоне синхронных групп все три серии (бабинская, криволукская и лолинская) обладают сходством как с выборками из кавказских могильников, так и с сериями шнурокерамических культур. При этом криволукская культурная группа, по мнению А.А. Казарницкого, сформировалась на основе предкавказских катакомбных и закавказских коллективов, а лолинская группа при участии населения упомянутых регионов при преобладающем компоненте потомков представителей катакомбных культур Предкавказья [Казарницкий, 2013б, c. 56, 59].

Сравнительный анализ черепов срубной культуры, который проводил А.А. Казарницкий, показал, что серия из Кривой Луки в среднем более короткоголовая, а также имеет большую симотическую высоту и менее широкую глазницу, чем серии из нижнедонских могильников. Кроме того, она имеет ряд специфических черт, которые были выявлены в результате проведения внутригруппового анализа. В ее структуре выделяются крайние морфологические варианты, на основе которых автор делает вывод о том, что палеопо- 
пуляция срубной культуры Кривой Луки (судя по мужской ее части) не была генетически замкнутой [Казарницкий, 2012, с. 123-126].

Материал раннего железного века хотя и изучался мною в ряде работ, но различные культурно-хронологические группы рассматривались либо в суммарных выборках, либо в качестве серий из групп Кривой Луки при межгрупповых сопоставлениях [Балабанова, 1999; $2000 ; 2005 ; 2007]$. Так, большую часть астраханской серии савроматского времени составляют черепа из курганных групп Кривой Луки, которая оказалась наиболее длинноголовой как по абсолютной длине черепа, так и по указателю, а также с высоким сводом, в отличие от других территориальных групп. При межгрупповых сопоставлениях астраханская локальная группа вместе с заволжской оказалась в кластере с тагарскими группами из Каменки I и Турана I (подгор. этап), предсавроматского времени с территории Нижнего Поволжья и Нижнего Дона и др. [Балабанова, 2000, c. 39-42].

При сопоставлении раннесарматских серий мужская и женская серии из Кривой Луки демонстрируют те же самые сочетания признаков, что и остальное синхронное население, то есть тип древних восточных европеоидов. Тем не менее именно краниологический тип групп из астраханского правобережья (Кривая Лука, Старица, Степной IV) и Заволжья (Эльтон, Бережновка II, Калиновка, Верхнепогромное и др.) можно считать характерным раннесарматским. Об этом же свидетельствуют результаты сравнительного анализа [Балабанова, 2000, с. 83, 84, 110, 111].

Немногочисленная мужская среднесарматская выборка из Кривой Луки на фоне других синхронных групп оказалась наиболее длинноголовой как по абсолютному значению продольного диаметра, так и по черепному указателю и вместе с группой Кузин из этого же региона демонстрирует тип длинноголовых европеоидов, который характерен для последующего, позднесарматского населения. При межгрупповых сопоставлениях она тяготеет к синхронному населению ВолгоДонского междуречья [Балабанова, 2000, c. $99,101,110,111,114]$.

Серии позднесарматского времени из Кривой Луки также использовались при меж- групповых сопоставлениях. В ходе выявления этногенетических связей населения раннесарматского и среднесарматского времени в сравнительном анализе использовалась только мужская серия недеформированных черепов. На фоне раннесарматских серий она демонстрирует «инаковость», а при аналогичном сопоставлении с группами среднесарматского времени попадает в кластер, в котором оказались как среднесарматские серии из Кузина и сборной серии Маныч-Сальского междуречья, так и позднесарматские. На четырехпольном графике в пространстве I и II канонических векторов позднесарматская серия из Кривой Луки расположилась рядом с позднесарматскими группами из Калмыкии (Купцын Толга, Джангр) и Заволжья (Бережновка I) [Балабанова, 2000, с. 114-117].

Кроме того, материал позднесарматского времени из могильников Кривой Луки рассматривался при изучении половозрастной структуры и краниологии территориальной группы могильников Астраханского Правобережья [Балабанова, 2007]. Численность серии, на основе которой дается анализ демографических структур, насчитывала 54 индивида. В результате исследования оказалось, что мужчин под позднесарматскими насыпями более чем в 2,5 раза больше, чем женщин. Детских захоронений всего три, в двух из которых погребены подростки старше 10 лет. Средний возраст дожития очень высокий около 45 лет. Большая часть умерших в момент смерти находилась в возрастной когорте Maturus-Senilis [Балабанова, 2007, c. 315]. Краниологическую серию по Кривой Луке представляют черепа без следов деформации (только мужские черепа) и с деформацией (мужские и женские черепа), доля которой $70,4 \%$. Обе мужские серии демонстрируют тип длинноголовых европеоидов, характерный для всего позднесарматского населения. Женская же серия деформированных черепов отличается мезобрахикранией, которая связана с наличием монголоидной примеси. Об этом свидетельствуют и средние размеры группы. Монголоидная примесь встречается и на мужских черепах из Кривой Луки. При анализе внутригрупповой структуры группы поздних сарматов астраханского правобережья монголоидная примесь выделяется второй глав- 
ной компонентой. При межгрупповых сопоставлениях обе мужские выборки демонстрируют сходство с аналогичными сериями из других территорий, а женская серия с деформацией - с серией из могильника Кермен Толга [Балабанова, 2007, с. 316-324].

Материал позднесарматского времени из Кривой Луки, а также хронологические серии раннесарматского и позднесарматского времени оттуда использовались при написании моей диссертации на соискание степени доктора исторических наук [Балабанова, 2013].

Что касается антропологических материалов эпохи средневековья, то серии золотоордынского времени были включены в диссертационное исследование Л.Т. Яблонским [1980]. Тема его работы не предполагала более детального их изучения, поэтому черепа из Кривой Луки вместе с другими черепами поздних кочевников использовались в межгрупповом сопоставлении.

Таким образом, разные культурно-хронологические группы антропологических материалов из могильников Кривой Луки были в той или иной степени исследованы. Цель нашей работы - отдельно опубликовать материалы савромато-сарматского населения, уделить внимание антропологическому типу и внутригрупповой структуре и ввести в научный оборот цифровую информацию по индивидуальным измерениям черепов обозначенных культурно-хронологических групп.

Методика и материал. Исследование антропологического материала проводилось по традиционной схеме [Алексеев, Дебец, 1964; Балабанова, 1998]. Индивидуальные характеристики по отдельным черепам использовались при подсчете средних значений и описании общего типа культурно-хронологических групп, а также для проведения внутригруппового анализа методами многомерной статистики, а в случае недостаточной численности выборок проводилась индивидуально-типологическая диагностика [Алексеев, Дебец, 1964; Дерябин, 1983; 1998]. Матрица внутригрупповых корреляций обрабатывалась методом многомерного неметрического шкалирования и кластерным анализом.

Вся антропологическая информация дается по черепам из погребений предсавроматского, савроматского, раннесарматского, сред- несарматского и позднесарматского времени. Всего было изучено 85 черепов, распределение их по полу, возрасту и культурно-хронологическим группам приведено в таблице 1 . Индивидуальные значения краниометрических признаков большей части материала впервые вводятся в научный оборот и представлены в таблице 2.

Антропологическая коллекция, с которой я работала в далекие 90-е годы XX в., хранится в Музее антропологии и этнографии имени Петpa Великого РАН, г. Санкт-Петербург.

Анализ. При характеристике культурнохронологических групп населения раннего железного века урочища Кривая Лука сначала определялся общий тип, затем проводился внутригрупповой анализ всего материала.

Краниология населения предсавроматского времени. Для получения представления об антропологическом типе населения этого времени имеются два черепа, которые были получены из погребений, отличающиеся своим обрядом. Оба черепа принадлежали мужчинам преклонного и зрелого возраста. Костяк, полученный при раскопках погребения 7 кургана 1 курганной группы II, лежал скорченно на левом боку, с согнутыми ногами в коленях, с восточной ориентировкой головы. При нем был обнаружен глиняный сосуд [Дворниченко и др., 1977, с. 15]. Индивидуальные измерения черепа позволяют отнести его к типу широкоголовых европеоидов, так как он сочетает короткую среднеширокую и средневысокую мозговую коробку с широким и высоким лицом, горизонтальная профилировка которого резкая (табл. 2,1).

Второй костяк, который был получен при раскопках парного погребения 22 кургана 1 курганной группы XXVIII, лежал вытянуто на правом боку с завалом направо, головой был ориентирован на запад-юго-запад. Мужчина был захоронен с ребенком. В погребении были найдены каменное плоское сланцевое точило у основания грудного отдела позвоночника и лежавшая под точилом костяная втульчатая стрела. Еще одна костяная втульчатая стрела находилась рядом [Федоров-Давыдов и др., 1979]. Череп мужчины из этого погребения более массивный, чем предыдущий, и характеризуется длинной, широкой и высокой мозговой коробкой, форма которой мезокранная, ортокран- 
ная и метриокранная. Лобная кость широкая, плоская в месте перегиба и прямая по линии назион-метопион (табл. 2,2). Лицевой скелет широкий и очень высокий с небольшим уплощением на уровне глазниц и резкой профилировкой на уровне скул, вертикальная профилировка его ортогнатная. Нос средневысокий и узкий, как по абсолютной ширине, так и по указателю. Глазница широкая и средневысокая и по высоте и по указателю (мезоконхная). Переносье узкое и очень высокое, а носовые кости средней ширины и тоже очень высокие с большим углом выступания носа.

Таким образом, несмотря на различия в индивидуальных характеристиках обоих черепов, видно их различие от предшествующего срубного населения, которое сочетало тип длинноголовых европеоидов.

Краниология населения савроматского времени. Мужская выборка состоит из 6 черепов в основном хорошей сохранности. Один череп принадлежал предположительно мальчику, которому на момент смерти было около 1012 лет. Его череп не учитывался при подсчетах средних значений, но включен в таблицу индивидуальных данных (табл. 2,3-9).

Мужская серия характеризуется длинной, среднеширокой и средневысокой, мезокранной и ортокранной черепной коробкой; широким и длинным основанием; широким и средненаклонным лбом, профилировка которого по углу поперечного изгиба резкая; средневысоким и широким ортогнатным лицом, умеренно профилированным в горизонтальной плоскости; широкими и средневысокими мезоконхными орбитами; средневысоким и среднешироким мезоринным, сильно выступающим носом; переносье и носовые кости средней ширины и высокие, а клыковая ямка глубокая (табл. 3).

Женская группа состоит из двух черепов, которые по средним значениям имеют мозговую коробку узкую, средней длины и высоты; пропорции тотальных размеров укладываются в мезокранию, ортокранию и метриокранию (табл. 3). Основание черепа средней ширины и длины, а лоб прямой, средней ширины и с резкой профилировкой по углу поперечного изгиба. Лицевой скелет мезоморфного строения по скуловой ширине и верхней высоте, с ослабленной горизонтальной и ортогнатной вертикальной профилировками. Нос узкий, низкий и мезоринный, а глазница низкая, средней ширины и мезоконхная. Переносье узкое и высокое, а носовые кости средней ширины и тоже высокие, резко выступающие. Клыковая ямка средней глубины.

Индивидуальные значения мужской серии позволяют говорить о большом размахе вариаций почти по всем признакам (табл. 2,3-9). При этом в серии представлены черепа, у которых тип широкоголовых европеоидов, характерный для населения этого времени, и тип длинноголовых европеоидов, характерный для предшествующего населения срубной культуры (рис. 1,1).

Краниология населения раннесарматского времени. Серия раннесарматского времени представлена двумя хронологическими периодами: IV-III вв. до н.э. и II-I вв. до н.э. (табл. 4). Ранняя серия немногочисленная и состоит из трех черепов - двух мужских и одного женского. Оба мужских черепа очень длинные по поперечному диаметру и долихокранные по указателю. Лицо средней ширины и высокое с умеренной горизонтальной профилировкой на обоих уровнях; носовые кости в одном случае узкие, а в другом - средней ширины, но высокие и резко выступающие (табл. 2,10-12).

Что касается женского черепа, то он принадлежал пожилой женщине и характеризуется короткой широкой и средневысокой мозговой коробкой брахикранной пропорции (табл. 2,12). Его основание широкое и средней длины, а лоб широкий, резко профилированный по горизонтали и сильно наклонный по вертикали. Лицо низкое, среднеширокое и резко профилированное на обоих горизонтальных уровнях и ортогнатное на вертикальном уровне. И нос, и орбита низкие, узкие; по пропорциям укладываются в мезоринию и хамэконхию. Переносье и носовые кости средней ширины и высокие с резким углом выступания носа.

Разнополые раннесарматские серии позднего этапа II-I вв. до н.э. более многочисленные и в сумме насчитывают 25 черепов. Как мужские черепа, так и женские относительно хорошей сохранности.

Мужская серия из 13 черепов и ее краниотип характеризуются среднедлинной и широкой мозговой коробкой, по форме брахикранной; со среднедлинным и широким основани- 
ем и широкой затылочной костью; лобная кость средней ширины, слегка наклонная и резко профилированная по линии фронтотемпоральных точек (табл. 4).

Лицо средней ширины и низкое, резко профилированное на верхнем горизонтальном уровне и с умеренной профилировкой на уровне зигомаксилярных точек, а в вертикальной плоскости обладает ортогнатной профилировкой; нос средней ширины и низкий, платиринный по указателю; глазницы широкие и низкие как по абсолютной высоте, так и по указателю (хамэконхные); переносье средней ширины, высокое, а носовые кости узкие и высокие и выводят нос к линии профиля резко. Клыковая ямка средней глубины.

Женская серия раннесарматского времени включает 12 черепов и по своим средним значениям отличатся от мужской тем, что она по продольному диаметру длинная, а по поперечному широкая с мезобрахикранной пропорцией (табл. 4). Высота свода средняя, а основание длинное и широкое. Что касается лобной кости, то она по наименьшей ширине широкая с резкой профилировкой в месте перегиба и слегка наклонная по линии назион-метопион.

Лицевой скелет также отличается от мужского и характеризуется большой шириной и средней высотой с умеренной горизонтальной профилировкой на обоих уровнях и ортогнатной вертикальной профилировкой. Нос мезоморфного строения по всем трем размерам: высоте, ширине и указателю $(55 ; 54$; 54:55). Орбиты широкие и средневысокие и по высоте и по указателю (мезоконхные). Переносье и носовые кости среднеширокие и высокие с сильно выступающим носом к линии профиля. Глубина клыковой ямки средняя.

Анализ среднеквадратических отклонений и дисперсий в обеих позднепрохоровских группах показывает завышенные значения по сравнению с приведенными в «Краниометрии ...», что, очевидно, свидетельствует о неоднородности разнополых групп [Алексеев, Дебец, 1964, табл. 12]. Так как анализ внутригрупповой структуры будет дан ниже, то здесь отметим, что в обеих сериях доминируют брахикранные черепа средних размеров и их тип определяется как тип древних восточных европеоидов, характеризующий облик савромато-раннесарматского населения Южного Приуралья, Нижнего Поволжья и Нижнего Дона (табл. 2,13-37) [Балабанова, 2000, c. $37,38,52-54]$. Таким образом, исследуемая группа из могильников урочища Кривая Лука является неотъемлемой частью населения Нижнего Поволжья VI-I вв. до н.э.

Краниология населения среднесарматского времени. Мужская серия насчитывает лишь три черепа хорошей сохранности, и в среднем они характеризуются длинной, среднеширокой и высокой черепной коробкой мезокранной формы; основание черепа длинное и средней ширины; лобная кость среднеширокая по наименьшей ее ширине, с резкой профилировкой (табл. 4). Лицевой скелет среднеширокий и средневысокий с резкой профилировкой на обоих горизонтальных уровнях и с ортогнатной вертикальной профилировкой; нос низкий, узкий и мезоринный; орбиты очень широкие и низкие, и по абсолютной высоте и по указателю (хамэконхные); переносье и носовые кости узкие и высокие, выводят нос к линии профиля сильно.

Индивидуальные измерения этих черепов демонстрируют различия, связанные с размером, а не типологического характера (табл. 2,38-40).

Краниология населения позднесарматского времени. Серия этого времени самая многочисленная и поделена на две части: серия со следами искусственной деформации (27 - мужских и 8 женских черепов) и серия без деформации (8 мужских черепов) (табл. 2,41-85). На черепах с деформацией регистрируются следующие типы: кольцевой, лобно-затылочный, комбинированный лобнозатылочный с кольцевым (рис. 1,2-5). Часть черепов несут на себе следы затылочной и теменно-затылочной деформации. Распределение разных типов деформации по группам существенных различий не имеет.

Обе краниологические серии (деформированные и недеформированные черепа) по средним значениям обладают большим сходством и диагностируются типом массивных длинноголовых европеоидов (табл. 5). Различия по сериям незначительные и в основном связаны с моделирующим эффектом деформации. Черепная коробка в обоих случаях длинная. Причем размах вариаций по продоль- 
ному диаметру чаще всего находится в пределах средних и очень больших величин. Короткий продольный диаметр встречается на черепах, у которых визуально определяется монголоидная примесь (рис. 1,2). Ширина черепной коробки в недеформированных группах средняя, а в деформированных - узкая. Соответственно, на деформированных черепах чаще определяются долихокранные пропорции с очень высоким сводом и от базиона-брегмы, и от порионов, а на недеформированных - долихо-мезокранные пропорции со средневысоким сводом. Различия затрагивают и основание черепа, лобную кость и лицевой скелет. Так, серия деформированных черепов характеризуется длинным и широким основанием, серия недеформированных черепов - средней длиной и широким основанием. Совершенно очевидно, что лобная кость также претерпевает изменения под давлением деформирующей конструкции. Она более широкая и покатая на деформированных черепах. Что касается лица, то оно выше и резче профилировано по горизонтальной профилировке, чем на недеформированных черепах. Кроме верхней высоты лица, на деформированных черепах нос, глазницы тоже выше. Это, а также небольшое снижение в области переносья и носовых костей, видимо, является результатом влияния деформирующей конструкции на признаки.

Женская часть деформированных черепов несколько отличается от обеих мужских серий, и ее мозговая коробка характеризуется средними значениями по длине и ширине, высоким сводом и мезобрахикранными формами. Основание черепа длинное и широкое, а лобная кость тоже широкая, резко профилированная в месте перегиба и покатая по линии назион-метопион. Лицо, как и в мужской серии деформированных черепов, широкое и высокое, но умеренно профилированное на обоих горизонтальных уровнях. Нос также высокий, среднеширокий и по абсолютной ширине, и по указателю (мезоринный). Орбиты крупные, широкие и высокие по абсолютной высоте, но средневысокие по указателю (мезоконхные). Переносье, как и в мужской серии, широкое и высокое, а носовые кости среднеширокие и высокие. Угол профиля носа средний (табл. 5).
Таким образом, обе мужские группы описываются по средним значениям одним и тем же типом, а отличия связаны с моделирующим эффектом деформирующей конструкции. Отличие женской серии деформированных черепов по средним значениям от мужской, видимо, связано с присутствием монголоидной примеси, о чем свидетельствуют и индивидуальные значения (табл. 2,41). О наличии монголоидной примеси в женской и мужской сериях из могильника астраханского правобережья я уже писала в отдельной работе [Балабанова, 2007, с. 319, 322].

Таким образом, вышеописанный средний тип культурно-хронологических групп Кривой Луки и проведенная индивидуальная типологическая диагностика свидетельствуют о морфологической неоднородности всех групп. Более детальный анализ внутригрупповой структуры проводился методом главных компонент, результаты которого приводятся ниже.

Внутригрупповой анализ. Для проведения данного анализа была суммирована цифровая информация по всем черепам относительно хорошей сохранности. В результате получили мужскую и женскую серии с выбранной программой признаков, в которой в первую очередь были исключены признаки, претерпевающие моделирующий эффект деформирующей конструкции. Поэтому вместо признаков были включены их производные, индексы и углы (табл. 6). Тем не менее полностью исключить эту проблему, видимо, мне удалось.

В результате анализа мужской серии было извлечено 6 главных компонент, а при анализе женской - 7 главных компонент с собственными числами больше единицы. Вклад первой главной компоненты (далее - I ГК) во внутригрупповую изменчивость невысокий, у мужчин - 20,0 \%, а у женщин - 25,0 \%. Повидимому, в обоих случаях она является компонентой размера, так как имеет высокие положительные нагрузки прежде всего с общеростовой величиной (ОРВ), условным трансверсальным сечением и объемом (М2 и М3). Кроме того, у мужчин I ГК разграничивает массивный тип, у которого затылочно-теменной индекс находится в вариациях монголоидных популяций, а лицо широкое и высокое (положительный полюс изменчивости), от грацильного типа с европеоидным показателем 
затылочно-теменного индекса и узким и низким лицом (отрицательный полюс изменчивости) [Беневоленская, 1980].

Самыми крупными и массивными мужскими черепами оказались черепа со следами искусственной деформации позднесарматского времени из погребения кургана 9 группы XVII и погребения кургана 17 группы XVI. У них общеростовая величина больше 280, условное трансверсальное сечение больше 270 , а условный трансверсальный объем больше 2000. Что касается лицевых параметров, то у них скуловая ширина больше 140 мм, а верхняя высота лица больше 80 мм (табл. 2,57,60). Противостоят им черепа раннесарматского времени из погребения 33 кургана 1 группы XVI и погребения 28 (костяк 2) кургана 1 группы III. Соответственно, эти же признаки для первого черепа имеют следующие значения: $255 ; 242,2 ; 1513,8 ; 133$ и 64 , а для второго - 260,9; 266,2; 1597,3; 131; 57 (табл. 2,20,34).

При анализе женской группы I ГК также имеет высокие корреляции с общеростовой величиной (ОРВ), условным трансверсальным объемом (М3), скуловой шириной (45) и верхней высотой лица (48). При этом все эти признаки имеют отрицательную нагрузку по этой переменной. С положительной корреляцией оказались максилофронтальный, дакриальный и симтический указатели и угол профиля носа. Согласно этим данным, на полюсах изменчивости, с одной стороны, локализуются черепа, у которых небольшой объем и значение общеростовой величины сочетается с узким, низким лицом, высоким переносьем и сильно выступающими носовыми костями, а с другой - черепа с альтернативными сочетаниями. Первый вариант является доминантой черепов из погребений раннесарматского и савроматского времени (погребение 15 кургана 1 группы VI и погребение 2 кургана 4 группы XXI) (табл. 2,6,22). Второй же вариант встречается на позднесарматском черепе - со следами деформации (погребение из кургана 8 группы XVII) (табл. 2,59).

Вторая главная компонента у мужчин отражает $15,6 \%$ внутригрупповой изменчивости и имеет средние и высокие корреляции с шириной лица (45), орбитным указателем (52:51) и профильными размерами (FC; 77;
$<$ zm' и 75-1). При этом положительные нагрузки падают на ширину лица, глубину клыковой ямки, на оба угла горизонтальной профилировки и угол выступания носа. С орбитным указателем у него средней степени связь и отрицательная по значению. Таким образом, максимальные положительные значения по этой компоненте имеют черепа, у которых широкое, умеренно профилированное лицо сочетается с низкими глазницами и сильно выступающим носом к линии профиля, а на отрицательном полюсе будут черепа с узким, резко профилированным в горизонтальной плоскости лицом, с высокими орбитами, мелкой клыковой ямкой и умеренно выступающим носом к линии профиля. Первый вариант встречается в большей степени на черепах раннесарматского и савроматского времени: из погребения 7 кургана 5 группы VIII; из погребения 28 костяк 2 кургана 1 группы III; из погребения 2 кургана 19 группы XVII и др. (табл. 2,4,20,28). Полное сочетание признаков второго варианта встречается на позднесарматском черепе из погребения кургана 18 группы VI (табл. 2,48).

У второй главной компоненты при анализе женской серии вклад во внутригрупповую изменчивость такой же, что и при анализе мужской группы - 15,5 \%, но высокие корреляции с другими признаками. Положительные корреляции у нее с условным трансверсальным сечением и объемом (M2 и М3), а отрицательные - с двумя углами вертикальной профилировки лица (72 и 74). Получается, что эта компонента разграничивает, с одной стороны, крупные черепа, у которых лицевой скелет с тенденцией к прогнатизму (череп из раннесарматского погребения 2 кургана 2 группы II), а с другой - черепа с альтернативным набором (череп из позднесарматского погребения кургана 2 группы I) (табл. 2,16,41).

При анализе и мужской и женской групп III и IV ГК отражают около $12,0 \%$ от общей изменчивости и описывают в основном признаки лицевого скелета. В обеих разнополых группах на III ГК наибольшие нагрузки падают прежде всего на угол поперечного изгиба лба, на носовой указатель и угол альвеолярной части лица (УПИЛ; 54:55 и 74). По IV ГК у мужчин высокие корреляции с признаками профиля переносья и носовых костей (MS:MC; 
DS:DC; SS:SC), а у женщин - с признаками, описывающими горизонтальный профиль лба и верхней части лица (УПИЛ и 77).

Кроме анализа нагрузок для выявления внутригрупповых зависимостей была построена дендрограмма кластеризации и четырехпольный график неметрического многомерного шкалирования матрицы внутригрупповых корреляций, которые также демонстрируют морфологическую неоднородность исследуемых групп (рис. 2, 3).

Средние значения черепов, объединенных в отдельные кластеры, которые можно считать реально существующими типами, сильно отличаются друг от друга. Таких групп - от двух до 12 черепов - всего девять в мужской серии и четыре в женской. И в мужской, и в женской сериях выделяется группа раннесарматских черепов с широким и низким лицом. Есть объединение черепов, у которых высокое и плоское в горизонтальной плоскости лицо. В эту связку попали черепа савроматского, раннесарматского и позднесарматского времени. Морфологической доминантой группы, в которой объединились оба черепа предсавроматского, два черепа савроматского и по два черепа раннесарматского и среднесарматского времени, является большое значение затылочно-теменного индекса. Отдельный кластер образовали 7 черепов позднесарматского времени со следами деформации. Из них три происходят из погребений курганной группы VI. Все они характеризуются долихокранией и средними значениями общеростовой величины, условного трансверсального сечения и объема. Крайние положения на графике занимают черепа, у которых, с одной стороны, малые размеры мозгового и лицевого отдела сочетаются с плоской горизонтальной профилировкой лица (в левом верхнем углу), а с другой - массивные черепа с резкой горизонтальной профилировкой лица (правый нижний угол графика).

Что касается женских групп, то группа из двух раннесарматских черепов объединилась по строению мозгового отдела, который имеет малые размеры, а угол выступания носа - максимальный в группе. Противостоит этой группе связка из двух черепов, которая сочетает крупные размеры мозгового отдела и умеренный угол выступания носа. В обоих случаях центральное положение на графике заняли черепа, которые характеризуются типом длинноголовых европеоидов.

Результаты и основные выводы. Суммируя результаты вышеизложенного анализа можно выделить следующие важнейшие моменты, связанные с антропологией населения раннего железного века, оставившего могильники Кривой Луки:

1. Морфологический облик культурнохронологических групп схож с остальным синхронным населением, как из других могильников Нижнего Поволжья, так и из сопредельных территорий. Для небольшой группы предсавроматского времени, как и для групп савроматского и раннесарматского времени, характерен сарматский тип, или тип древних восточных европеоидов, который сочетает мезо-брахикранию с умеренной горизонтальной профилировкой лицевого скелета на верхнем уровне при резко выступающем носе. Небольшая среднесарматская мужская группа демонстрирует сочетания, которые характеризуют последующее позднесарматское население. Для него характерен тип длинноголовых европеоидов, который преобладает у мужской части исследуемой популяции. Женский краниологический тип позднесарматского времени характеризуется набором признаков, определяющих тип монголоидно-европеоидных метисов.

2. Как суммарная группа черепов, так и отдельные культурно-хронологические группы оказались по внутригрупповой структуре неоднородными. В группах предсавроматского, савроматского и раннесарматского времени преобладает тип широкоголовых европеоидов с некоторыми внутригрупповыми вариациями по горизонтальной профилировке лица; в группах среднесарматского и позднесарматского времени - тип длинноголовых европеоидов с массивным и грацильным строением мозгового и лицевого отделов черепа.

3. В группах савроматского, раннесарматского и позднесарматского времени встречаются черепа, сочетающие монголоидноевропеоидный комплекс. Особенно велик его вес в женской позднесарматской группе со следами деформации.

Подводя итоги вышесказанному, следует отметить, что средние значения групп на- 
M.A. Balabanova. Anthropological Composition of the Population of the Early Iron Age from the Lower Volga Region

селения раннего железного века, оставившего могильники в урочище Кривая Лука, демонстрируют диахронную изменчивость, которая, видимо, была связана с миграциями. Уже в предсавроматское время по сравнению с поздней бронзой на этой территории большой вес приобретает тип древних восточных европеоидов, который сочетает мезобрахикранную низкосводчатую мозговую коробку с широким лицом, горизонтальная профилировка которого на верхнем уровне ослаблена, а нос резко выступающий к линии профиля. Он продержался здесь до рубежа эр, а начиная со среднесарматского времени меняется на тип длинноголовых европеоидов, который связан с проникновением пришлых групп. Среди этих мигрантов, видимо, были и носители смешанного монголоидно-европеоидного комплекса.

\section{Благодарности}

Автор выражает благодарность заведующему отделом антропологии Музея антропологии и этнографии имени Петра Великого (Кунсткамера) и его сотрудникам за предоставленную возможность работать с краниологическими материалами в начале 90-х гг. XX столетия.

\section{ПРИМЕЧАНИЕ}

${ }^{1}$ Исследование выполнено при финансовой поддержке РФФИ, проект «Палеоантропология древнего и средневекового населения Нижнего Поволжья (палеопатологический аспект)», № 19-09-00471А.

The research was supported by RFBR grant "Paleoanthropology of the ancient and medieval population of the Lower Volga River region (paleopathological aspect)", № 19-09-00471A. 
M.А. Балабанова. Антропологический состав населения раннего железного века Нижнего Поволжья

\section{ИЛЛЮСТРАЦИИ}

Таблица 1. Перечень антропологического материала из курганных групп Кривой Луки

Table 1. A list of the anthropological material from the kurgan groups of the Krivaya Luka

\begin{tabular}{|c|c|c|c|}
\hline № ח/ח & Курганная группа, курган, погребение & Пол & Возраст (лет) \\
\hline \multicolumn{4}{|c|}{ Предсавроматское время } \\
\hline 1 & II, кург. 1, погр. 7 & की & Ст. 50 \\
\hline 2 & XXVIII, кург. 1, погр. 22 & $\delta$ & СТ. 50 \\
\hline \multicolumn{4}{|c|}{ Савроматское время (V-IV вв. до н.э.) } \\
\hline 3 & III, кург. 1, погр. 5 & $\hat{\delta}$ & $20-25$ \\
\hline 4 & XVII, кург. 19, погр. 2 & 8 & Ст. 50 \\
\hline 5 & XXI, кург. 1, погр. 6 & Q & Ст. 50 \\
\hline 6 & XXI, кург. 4, погр. 2 & O & $16-18$ \\
\hline 7 & XXVIII, кург. 1, погр. 18 & $\hat{\delta}$ & $18-20$ \\
\hline 8 & XXXV, кург. 1, погр. 3 & 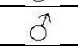 & $18-20$ \\
\hline 9 & XXXV, кург. 1, погр. 13 & 8 & $20-30$ \\
\hline \multicolumn{4}{|c|}{ Раннепрохоровское время (IV-III вв. до н.э.) } \\
\hline 10 & $\mathrm{XV}$, кург. 2, погр. 8 & 8 & Ст. 50 \\
\hline 11 & XVI, кург. 1, погр. 20 & sic & СТ. 50 \\
\hline 12 & XVI, кург. 10, погр. 2 & q & Ст. 50 \\
\hline \multicolumn{4}{|c|}{ Позднепрохоровское время (II-I вв. до н.э.) } \\
\hline 13 & I, кург. 1, погр. 1, костяк 1 & $\delta$ & $35-45$ \\
\hline 14 & I, кург. 1, погр. 1, костяк 2 & 8 & $20-25$ \\
\hline 15 & II, кург. 1, погр. 4 & 9 & Ст. 50 \\
\hline 16 & II, кург. 2, погр. 2 & 운 & Ст. 50 \\
\hline 17 & II, кург. 2, погр. 8 & 8 & $16-18$ \\
\hline 18 & III, кург. 1, погр. 26, костяк 1 & $\delta$ & Ст. 50 \\
\hline 19 & III, кург. 1, погр. 28, костяк 1 & $\delta$ & Ст. 50 \\
\hline 20 & III, кург. 1, погр. 28, костяк 2 & $\delta$ & $40-45$ \\
\hline 21 & IV, кург. 1, погр. 10 & 9 & Ст. 50 \\
\hline 22 & VI, кург. 1, погр. 15 & 오 & $45-50$ \\
\hline 23 & VIII, кург. 2, погр. 14 & 9 & Ст. 50 \\
\hline 24 & VIII, кург. 4, погр. 3 & 9 & $45-55$ \\
\hline 25 & VIII, кург. 4, погр. 4 & 웅 & $18-20$ \\
\hline 26 & VIII, кург. 5, погр. 2, костяк 1 & + & $30-40$ \\
\hline 27 & VIII, кург. 5, погр. 2, костяк 2 & 3 & $50-60$ \\
\hline 28 & VIII, кург. 5, погр. 7 & $\delta$ & $45-55$ \\
\hline 29 & IX, кург. 2, погр. 10 & 9 & $20-25$ \\
\hline 30 & IX, кург. 2, погр. 15 & 운 & Ст. 50 \\
\hline 31 & XII, кург. 1, погр. 6 & 9 & Ст. 50 \\
\hline 32 & XIV, кург. 16, погр. 1 & 8 & Ст. 50 \\
\hline 33 & XVI, кург. 1, погр. 30 & O & $35-45$ \\
\hline 34 & XVI, кург. 1, погр. 33 & 8 & Ст. 50 \\
\hline 35 & XVI, кург. 4, погр. 2 & $\delta$ & Ст. 50 \\
\hline 36 & XXVIII, кург. 1, погр. 6, костяк 1 & $\hat{3}$ & Ст. 50 \\
\hline 37 & KXXVIII, кург. 1, погр. 20, костяк 1 & 3 & Ст. 50 \\
\hline \multicolumn{4}{|c|}{ Среднесарматское время (I - первая половина II в. н.э.) } \\
\hline 38 & XVI, кург. 11, погр. 1 & 8 & Ст. 50 \\
\hline 39 & XVII, кург. 25, погр. 3 & $\hat{S}$ & Ст. 50 \\
\hline 40 & XXII, кург. 1, погр. 2 & $\hat{0}$ & Ст. 50 \\
\hline
\end{tabular}


M.A. Balabanova. Anthropological Composition of the Population of the Early Iron Age from the Lower Volga Region

\section{Окончание таблиць 1}

End of Table 1

\begin{tabular}{|c|c|c|c|c|}
\hline № $\Pi / \Pi$ & Курганная группа, курган, погребение & Пол & Возраст (лет) & Наличие деформации \\
\hline \multicolumn{5}{|c|}{ Позднесарматское время (вторая половина II - IV в. н.э.) } \\
\hline 41 & I, кург. 2 & 9 & $35-45$ & + \\
\hline 42 & I, кург. 5 & की & $25-35$ & - \\
\hline 43 & I, кург. 7 & 3 & Ст. 50 & + \\
\hline 44 & I, кург. 9 & 운 & Ст. 50 & + \\
\hline 45 & I, кург. 10 & 3 & Ст. 50 & + \\
\hline 46 & VI, кург. 3 & 3 & Ст. 50 & + \\
\hline 47 & VI, кург. 4 & $0^{2}$ & Ст. 50 & + \\
\hline 48 & VI, кург. 10 & $\delta$ & Ст. 50 & + \\
\hline 49 & VI, кург. 13 & के & $40-50$ & - \\
\hline 50 & VI, кург. 14 & 3 & $18-25$ & - \\
\hline 51 & VI, кург. 18 & $\hat{6}$ & Ст. 50 & + \\
\hline 52 & VII, кург. 2 & 3 & $40-50$ & - \\
\hline 53 & IX, кург. 5, погр. 2 & 3 & Ст. 50 & + \\
\hline 54 & XIV, кург. 9, погр. 3 & 3 & Ст. 50 & + \\
\hline 55 & XIV, кург. 10 & 3 & $18-20$ & + \\
\hline 56 & XIV, кург. 11 & 3 & $25-35$ & - \\
\hline 57 & XIV, кург. 14 & 3 & Ст. 50 & + \\
\hline 58 & XVI, кург. $1 / 16$, костяк 1 & $\hat{\jmath}$ & Ст. 50 & + \\
\hline 59 & XVI, кург. 9 & 3 & $25-35$ & - \\
\hline 60 & XVI, кург. 12 & 3 & Ст. 50 & + \\
\hline 61 & XVI, кург. 13 & $\hat{0}$ & Ст. 50 & + \\
\hline 62 & XVI, кург. 16 & -3. & Ст. 50 & + \\
\hline 63 & XVI, кург. 17 & 3 & Ст. 50 & + \\
\hline 64 & XVI, кург. 19 & $\hat{3}$ & Ст. 50 & - \\
\hline 65 & XVII, кург. 7 & 3 & $30-40$ & + \\
\hline 66 & XVII, кург. 8 & 우 & Ст. 50 & + \\
\hline 67 & XVII, кург. 9 & की & Ст. 50 & + \\
\hline 68 & XVII, кург. 12 & 오 & Ст. 50 & + \\
\hline 69 & XVII, кург. 13 & 3 & $35-45$ & - \\
\hline 70 & XVII, кург. 14 & 6 & $25-30$ & + \\
\hline 71 & XVII, кург. 17 & 우 & $16-18$ & + \\
\hline 72 & XVII, кург. 20 & 3 & Ст. 50 & + \\
\hline 73 & XVII, кург. 21 & 3 & Ст. 50 & + \\
\hline 74 & XVII, кург. 22 & $\delta$ & Ст. 50 & + \\
\hline 75 & XVII, кург. 23 & q? & $10-12$ & + \\
\hline 76 & XVII, кург. 30 & p & $30-40$ & + \\
\hline 77 & XVII, кург. 32 & 0 & $30-40$ & + \\
\hline 78 & XVII, кург. 33 & 3 & $14-15$ & + \\
\hline 79 & XVII, кург. 39 & - & $45-55$ & + \\
\hline 80 & XVII, кург. 41 & 3 & Ст. 50 & + \\
\hline 81 & XVII, кург. 42 & 우 & Ст. 50 & + \\
\hline 82 & XVII, кург. 44 & $\pi$ & Ст. 50 & + \\
\hline 83 & XVII, кург. 45 & 3 & Ст. 50 & + \\
\hline 84 & XVII, кург. 51 (?) & 3 & Ст. 50 & + \\
\hline 85 & XVII-KM (?), п. 1 (?) ${ }^{2}$ & की & Ст. 50 & + \\
\hline
\end{tabular}

Примечания. ${ }^{1}$ - при изучении черепа на пакете надпись была подпорчена, но так как череп с искусственной деформацией, то я включила его в позднесарматскую серию; ${ }^{2}$ - именно такая надпись на пакете, в котором находился череп, но так как в отчете нет такого кургана, а череп с искусственной деформацией, то я включила его в позднесарматскую серию. 
М.А. Балабанова. Антропологический состав населения раннего железного века Нижнего Поволжья

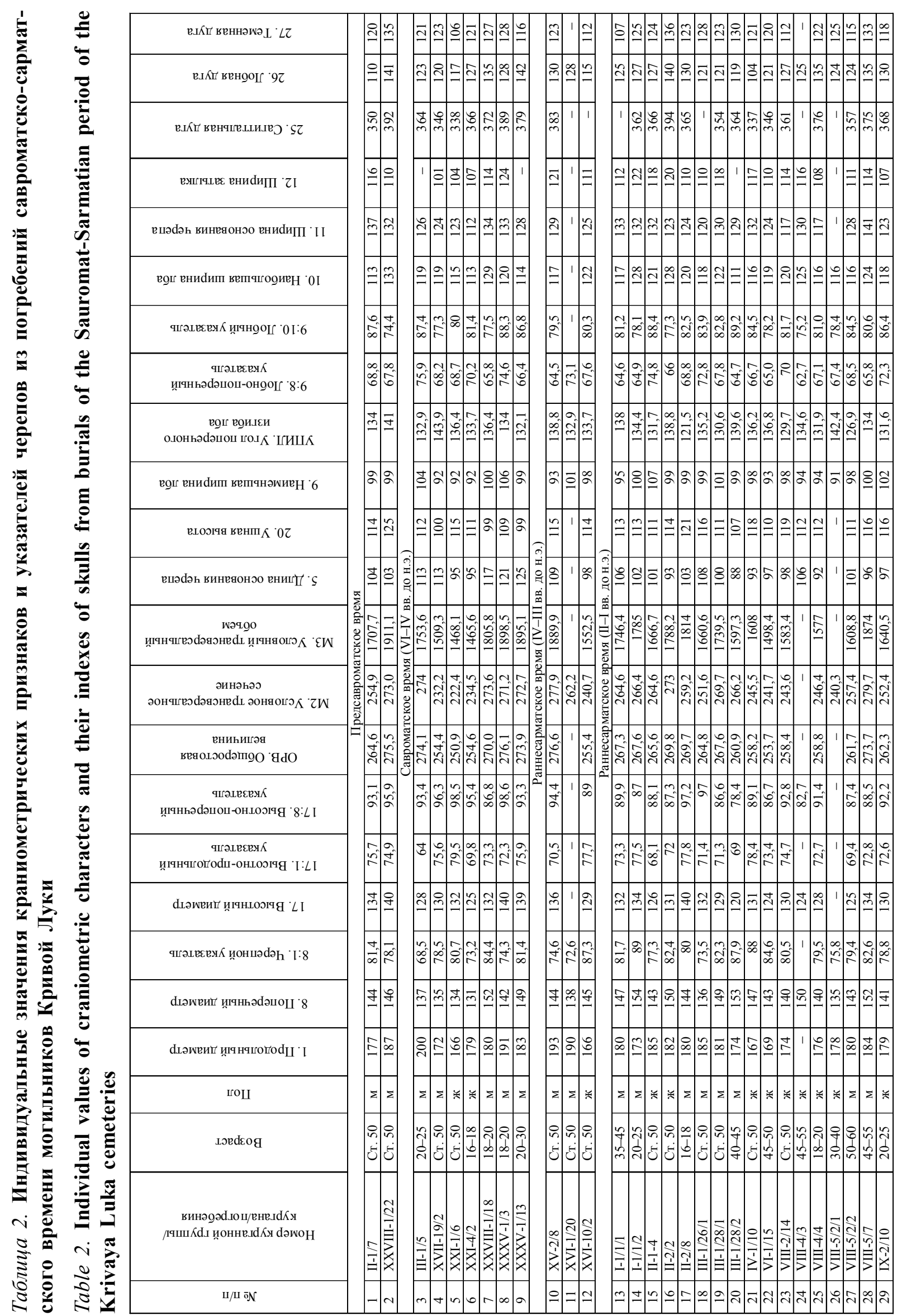


M.A. Balabanova. Anthropological Composition of the Population of the Early Iron Age from the Lower Volga Region

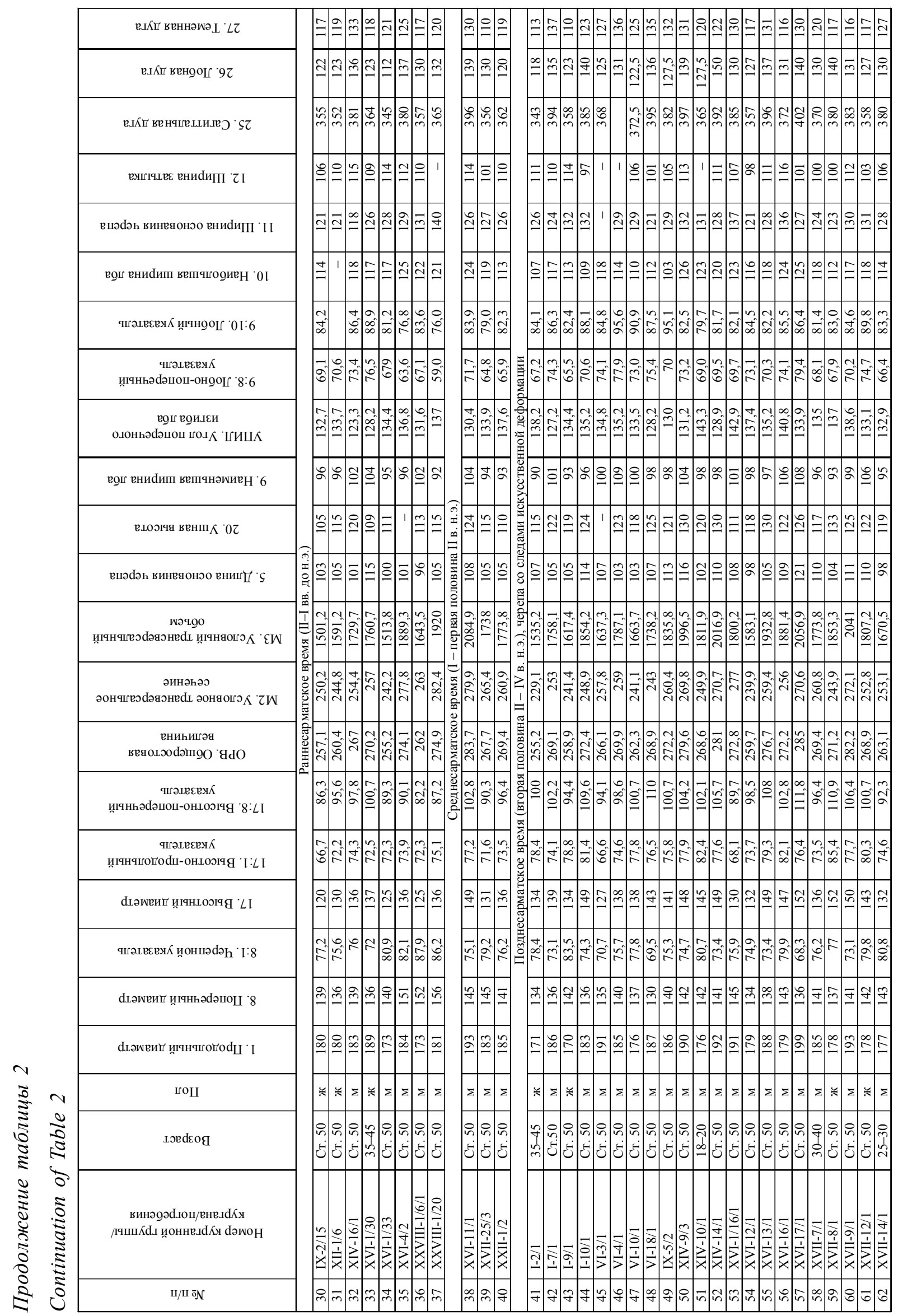


M.А. Балабанова. Антропологический состав населения раннего железного века Нижнего Поволжья

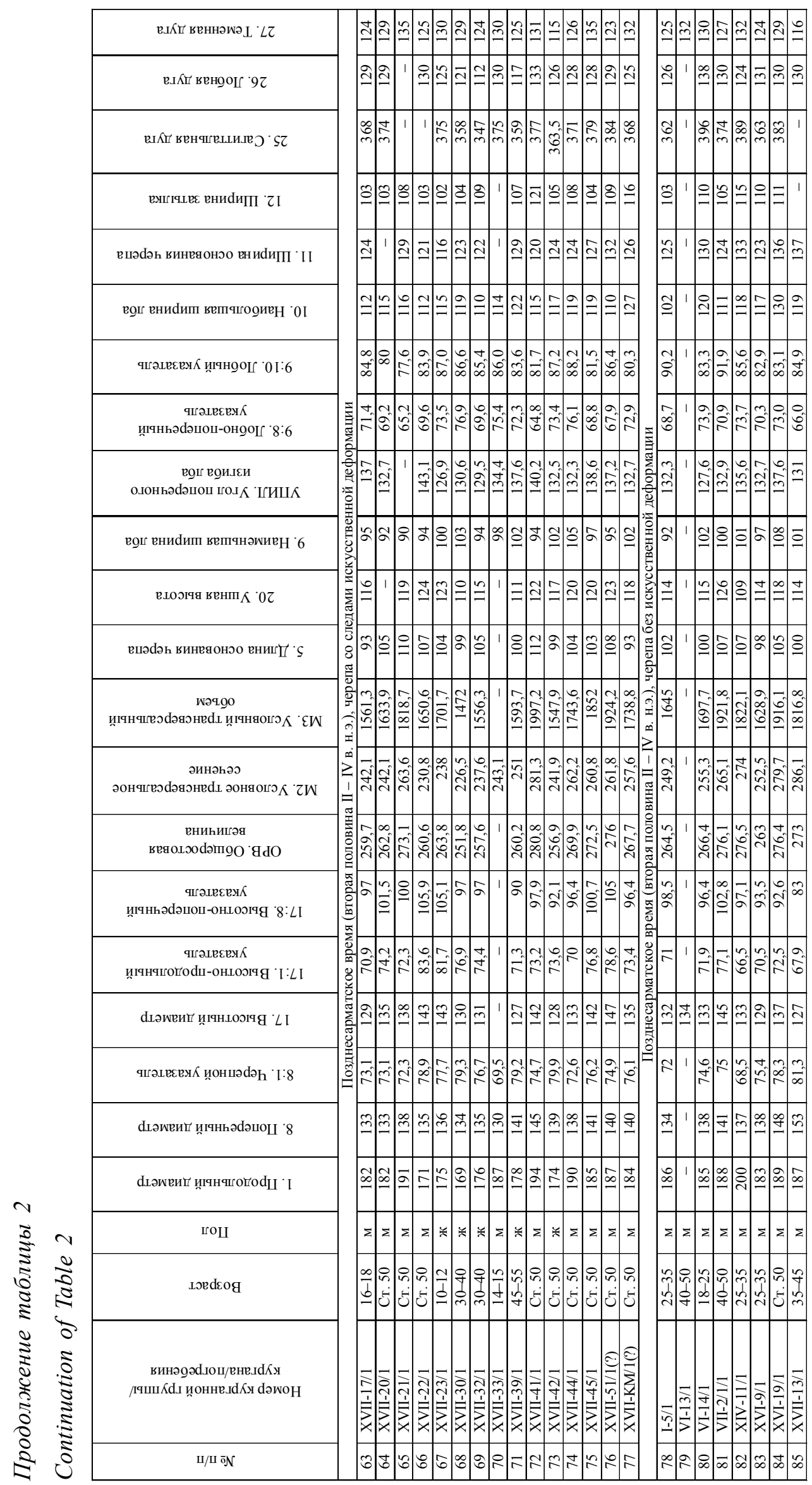




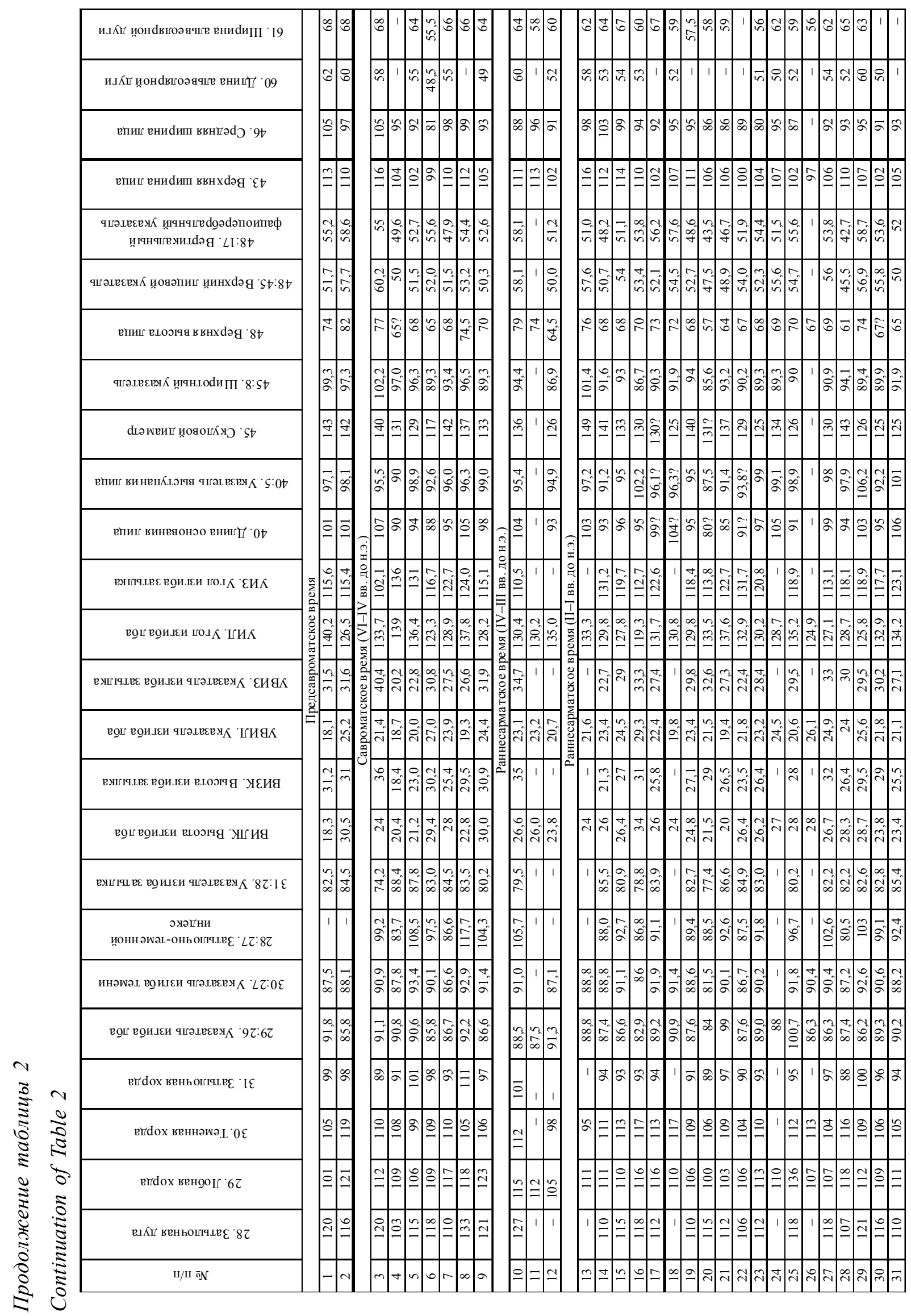




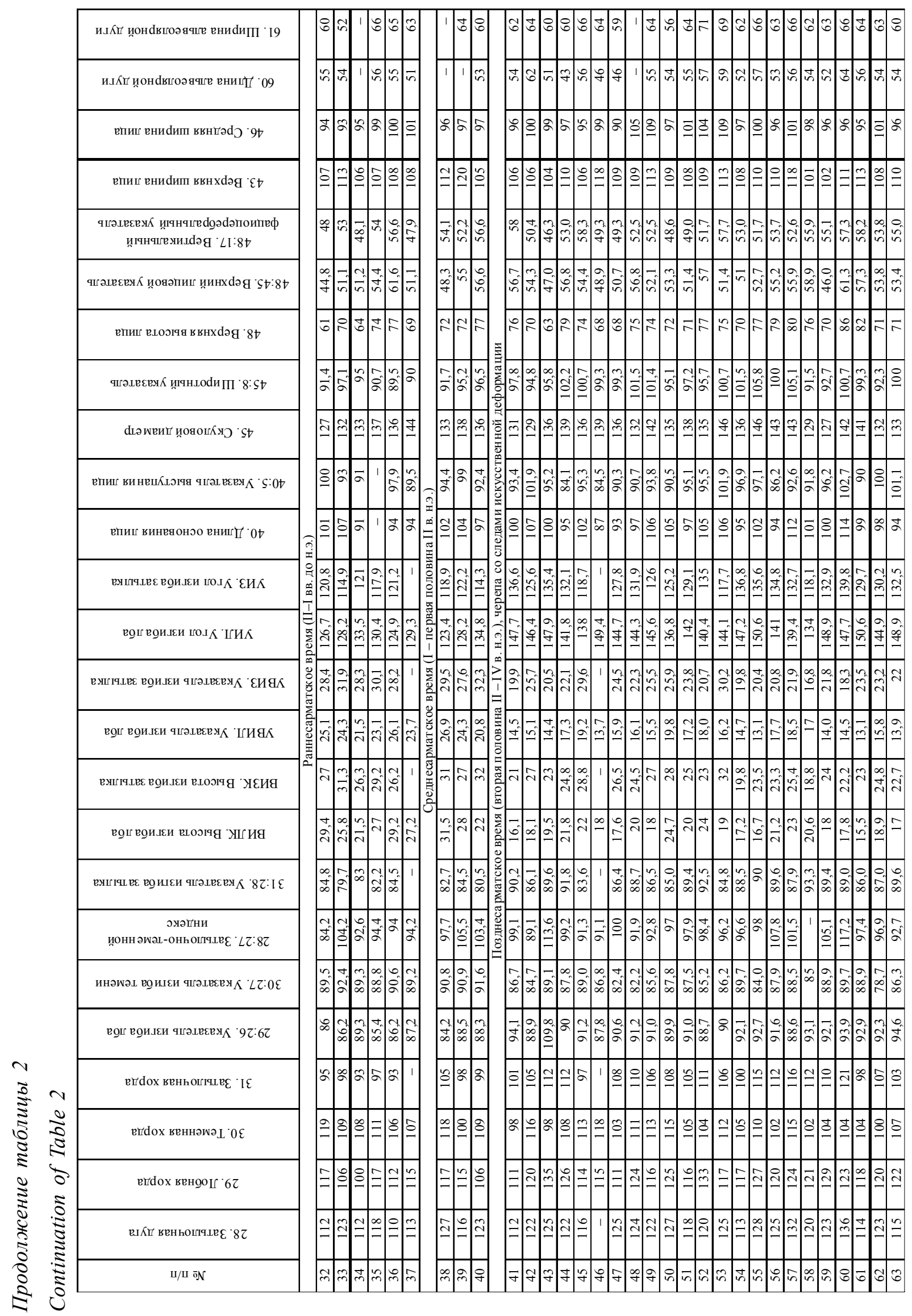




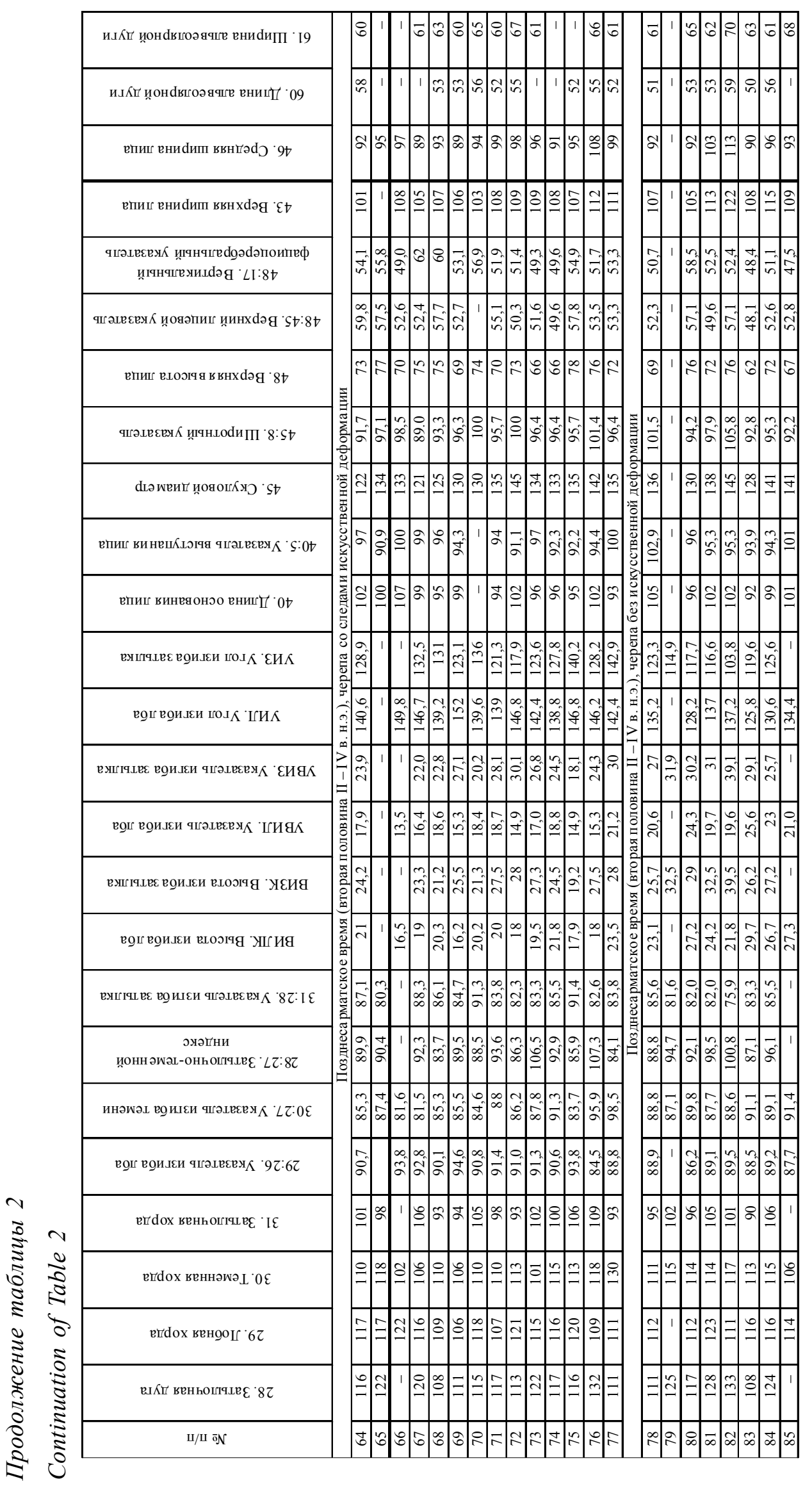




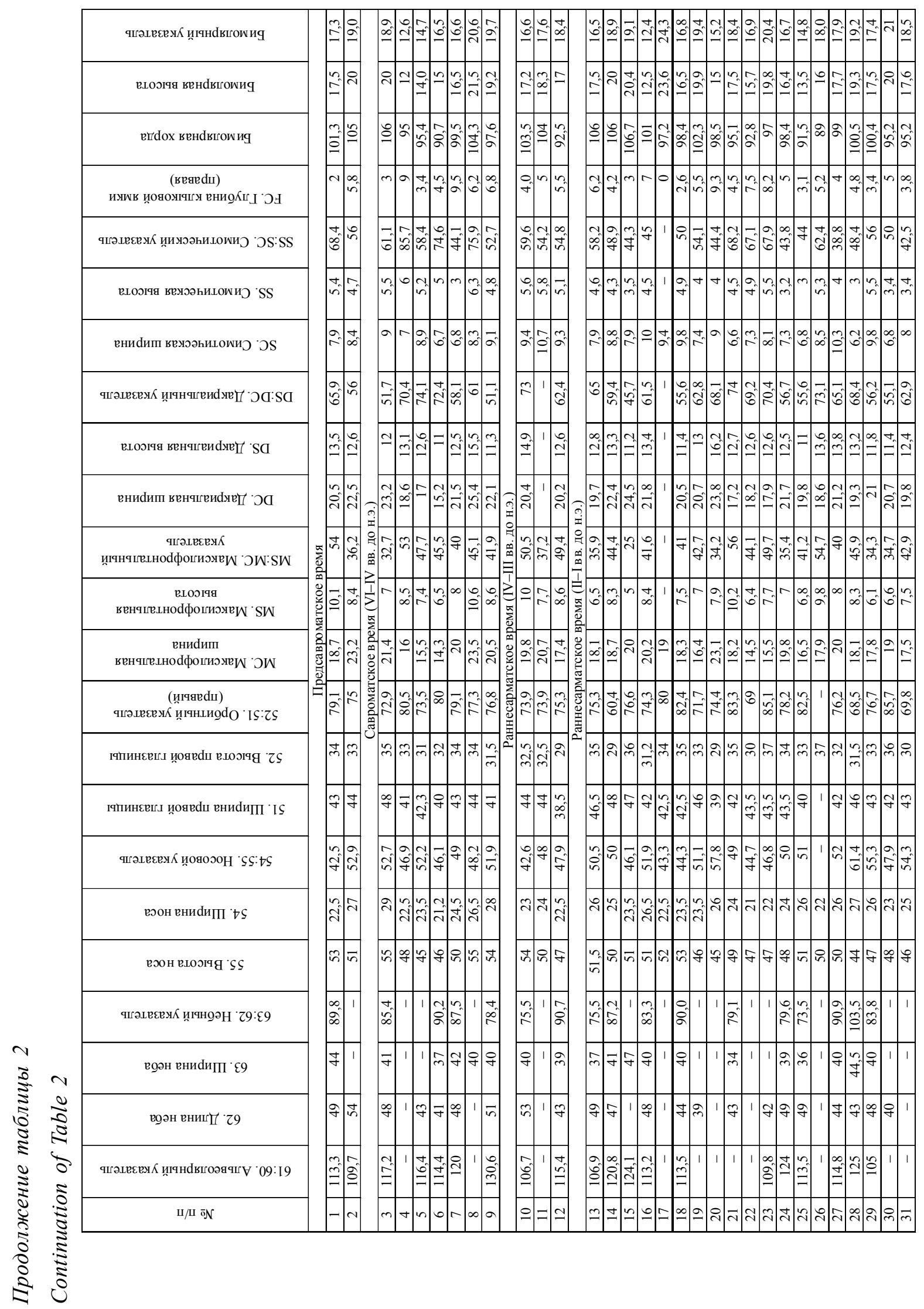




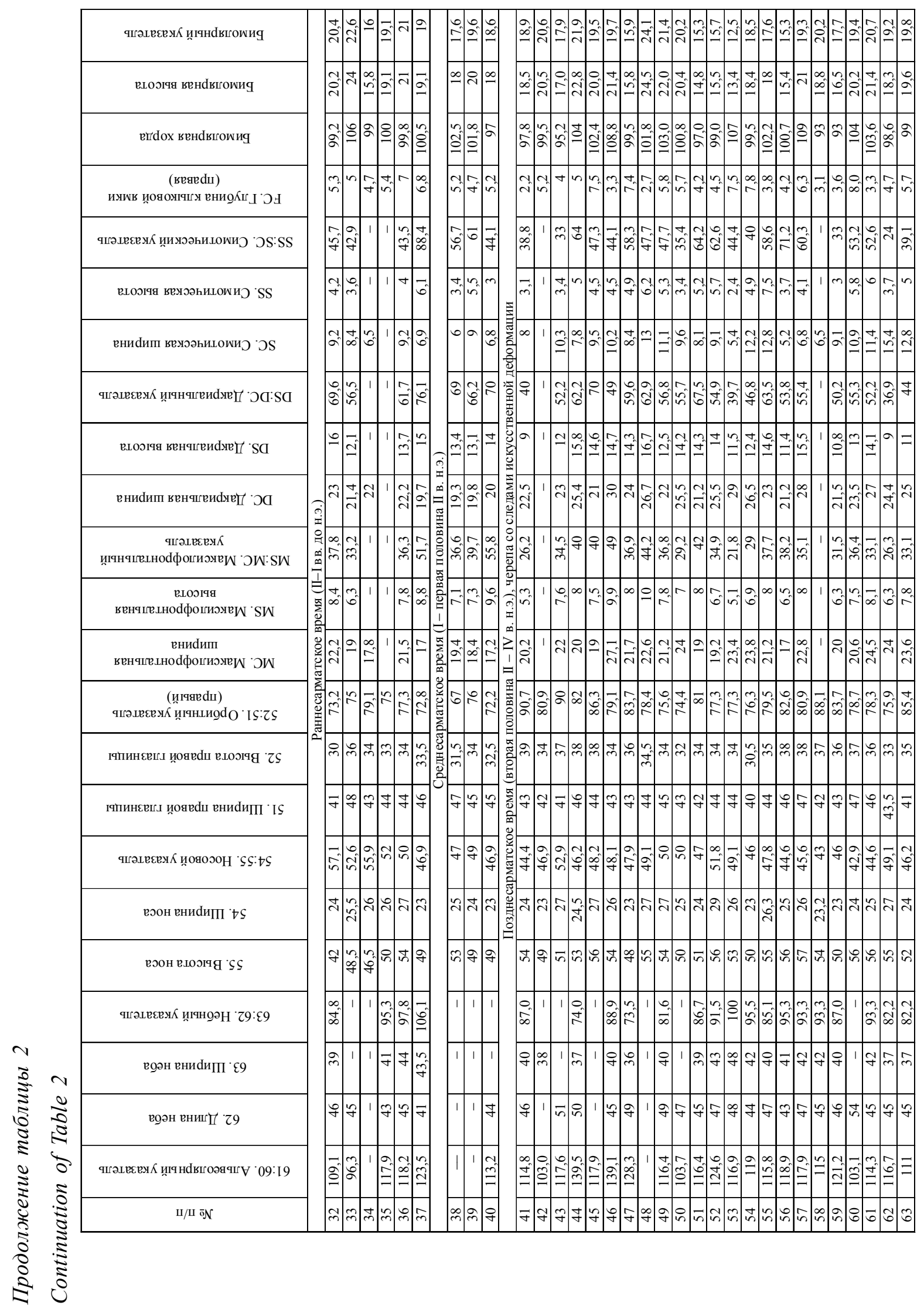




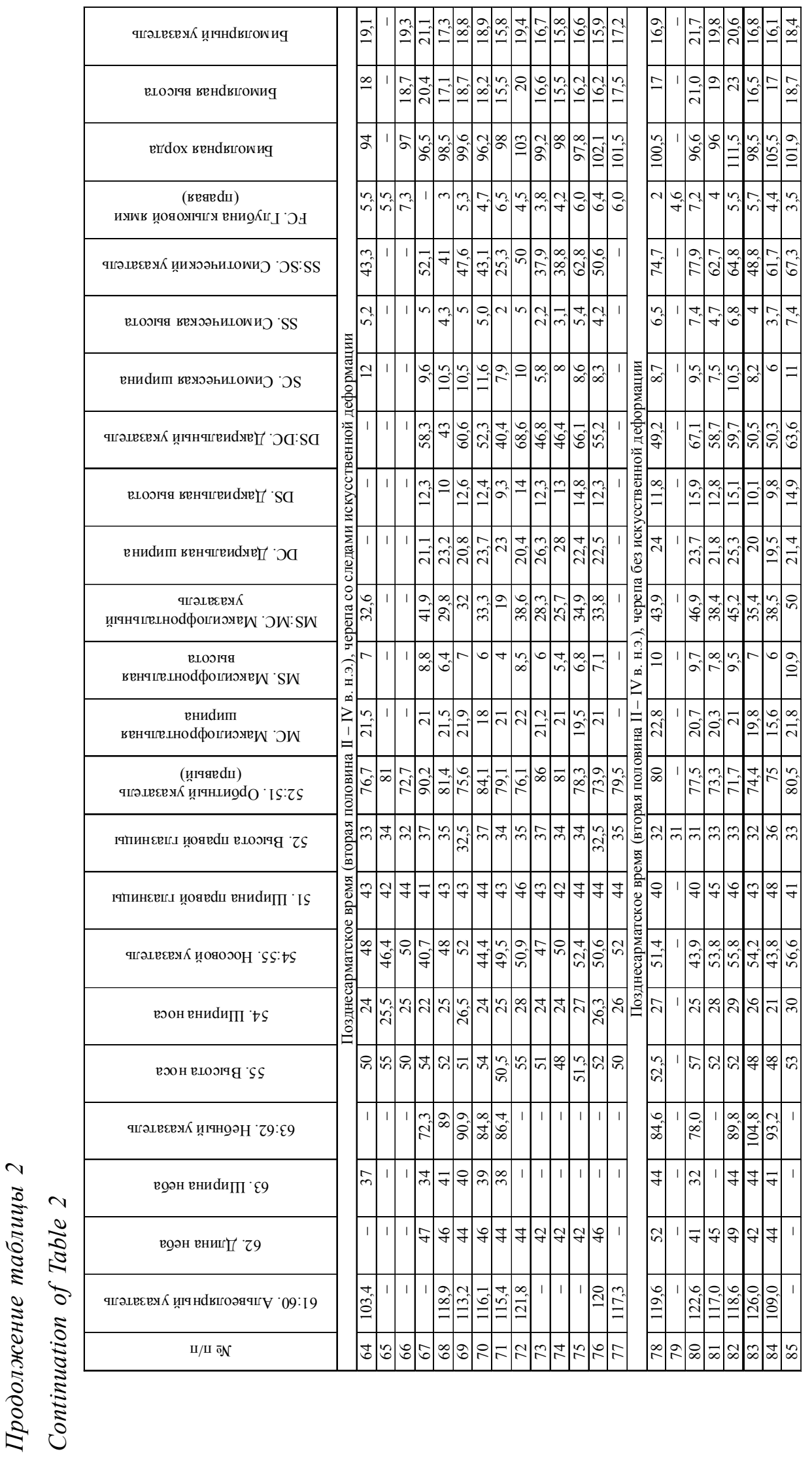




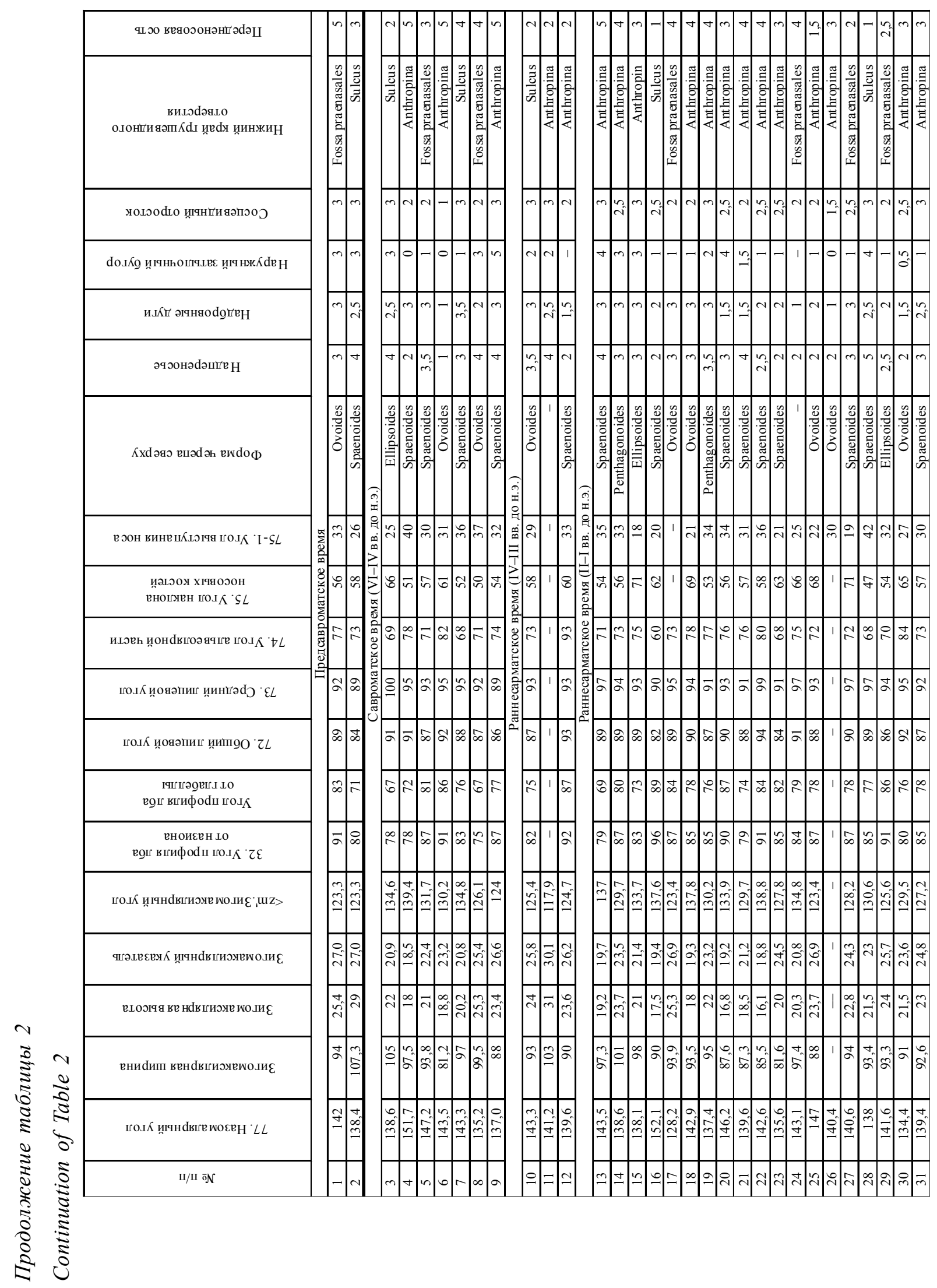

The Lower Volga Archaeological Bulletin. 2020. Vol. 19. No. 2 


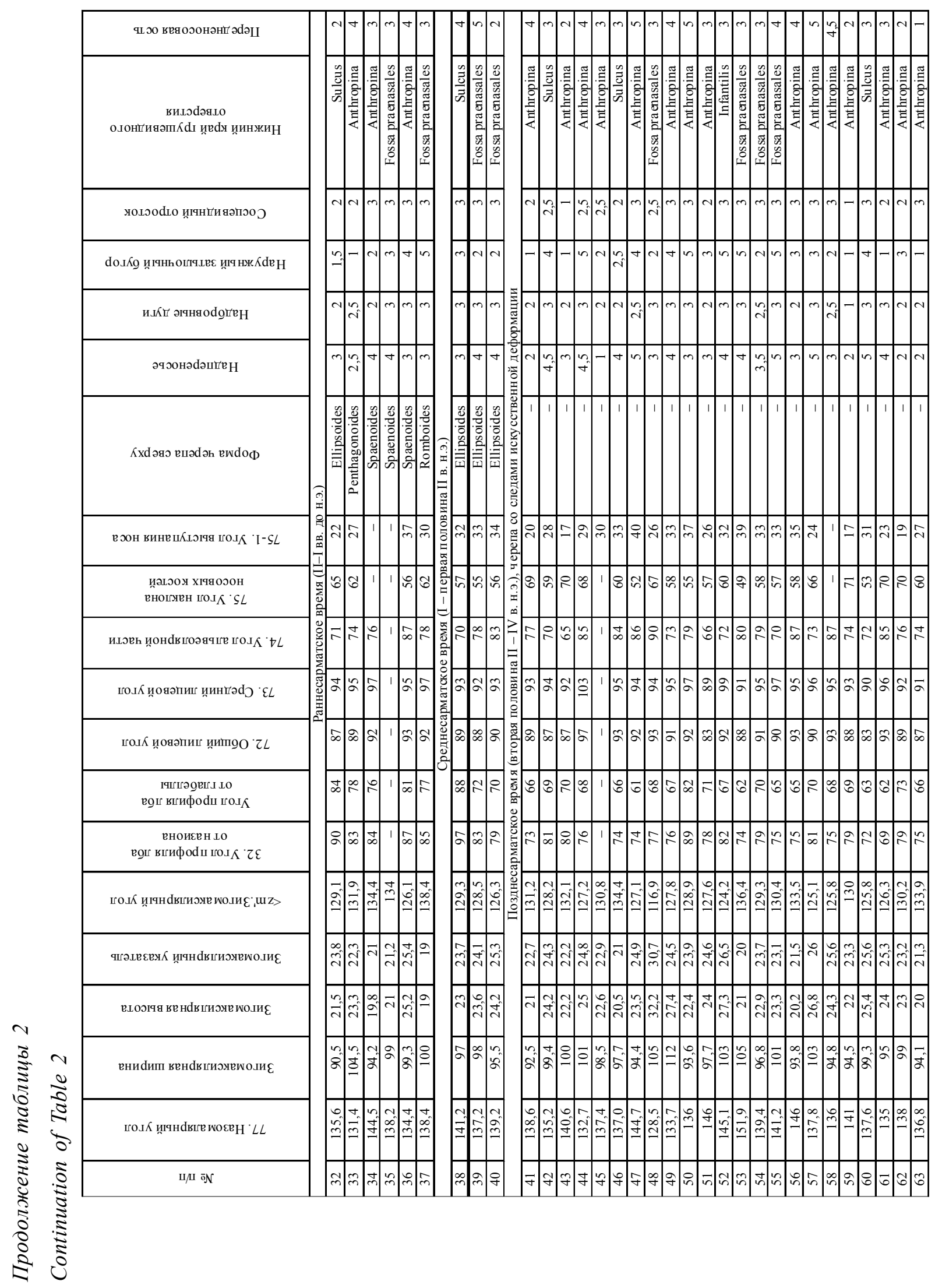




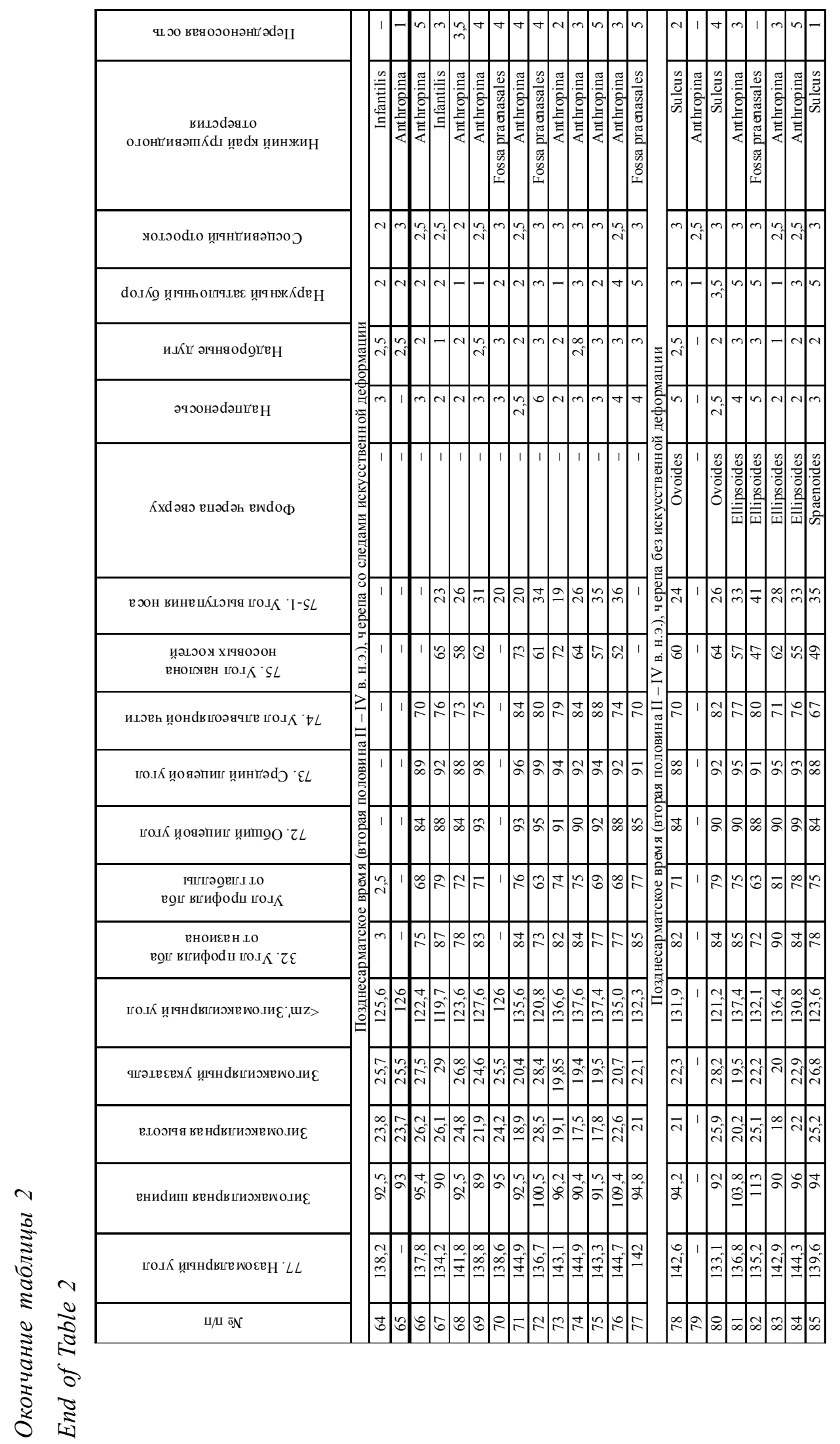


M.А. Балабанова. Антропологический состав населения раннего железного века Нижнего Поволжья

Таблица 3. Средние размеры и указатели краниологических серий предсавроматского и савроматского времени

Table 3. Average sizes and indexes of craniological series of the pre-Sauromatian and Sauromat times

\begin{tabular}{|c|c|c|c|c|c|c|c|}
\hline \multirow{3}{*}{$\begin{array}{c}\text { № по } \\
\text { Мартину } \\
\text { и др. }\end{array}$} & \multicolumn{5}{|c|}{ Мужские серии } & \multicolumn{2}{|c|}{ Женская серия } \\
\hline & \multicolumn{2}{|c|}{$\begin{array}{c}\text { Предсавроматское } \\
\text { время }\end{array}$} & \multicolumn{5}{|c|}{ Савроматское время } \\
\hline & $\mathrm{n}$ & $\mathrm{X}$ & $\mathrm{n}$ & $\mathrm{X}$ & $\mathrm{s}$ & $\mathrm{n}$ & $\mathrm{X}$ \\
\hline 1 & 2 & 182,0 & 5 & 185,2 & 10,7 & 2 & 172,5 \\
\hline 8 & 2 & 145,0 & 5 & 143,0 & 7,4 & 2 & 132,5 \\
\hline $8: 1$ & 2 & 79,8 & 5 & 77,4 & 6,2 & 2 & 77,0 \\
\hline 17 & 2 & 137 & 5 & 133,8 & 5,4 & 2 & 128,5 \\
\hline $17: 1$ & 2 & 73,5 & 5 & 72,2 & 4,8 & 2 & 74,65 \\
\hline $17: 8$ & 2 & 94,5 & 5 & 93,7 & 4,4 & 2 & 97,0 \\
\hline $\mathrm{OPB}$ & 2 & 270,0 & 5 & 269,7 & 8,85 & 2 & 252,7 \\
\hline M2 & 2 & 264,0 & 5 & 264,7 & 18,2 & 2 & 228,5 \\
\hline M3 & 2 & 1809,4 & 5 & 1772,45 & 159,4 & 2 & 1466,8 \\
\hline 5 & 2 & 103,5 & 5 & 103,8 & 6,2 & 2 & 95,0 \\
\hline 20 & 2 & 119,5 & 5 & 117,8 & 5,2 & 2 & 113,0 \\
\hline 9 & 2 & 99,0 & 5 & 100,2 & 5,4 & 2 & 92,0 \\
\hline УПИЛ & 2 & 137,5 & 5 & 135,9 & 4,8 & 2 & 135,05 \\
\hline 11 & 2 & 134,5 & 5 & 129,0 & 4,4 & 2 & 117,5 \\
\hline $28: 27$ & 2 & 93,0 & 5 & 97,4 & 12,2 & 2 & 103,0 \\
\hline 45 & 2 & 142,5 & 5 & 136,6 & 4,6 & 2 & 123,0 \\
\hline 40 & 2 & 101 & 5 & 99 & 7,0 & 2 & 91,0 \\
\hline $40: 5$ & 2 & 97,6 & 5 & 95,4 & 3,3 & 2 & 95,8 \\
\hline 48 & 2 & 78 & 5 & 70,9 & 4,85 & 2 & 66,5 \\
\hline 43 & 2 & 111,5 & 5 & 109,4 & 5,0 & 2 & 100,5 \\
\hline 46 & 2 & 101 & 5 & 97,8 & 4,6 & 2 & 86,5 \\
\hline 54 & 2 & 24,8 & 5 & 26,1 & 2,6 & 2 & 22,25 \\
\hline 55 & 2 & 52,0 & 5 & 52,4 & 3,2 & 2 & 45,5 \\
\hline $54: 55$ & 2 & 47,7 & 5 & 49,7 & 2,5 & 2 & 49,2 \\
\hline 51 & 2 & 43,5 & 5 & 43,4 & 2,9 & 2 & 41,0 \\
\hline 52 & 2 & 33,5 & 5 & 33,6 & 1,1 & 2 & 31,5 \\
\hline $52: 51$ & 2 & 77,0 & 5 & 77,3 & 2,9 & 2 & 76,65 \\
\hline $\mathrm{DC}$ & 2 & 21,5 & 5 & 22,2 & 2,5 & 2 & 16,1 \\
\hline $\mathrm{DS}$ & 2 & 13,05 & 5 & 12,9 & 1,6 & 2 & 11,8 \\
\hline DS:DC & 2 & 61,0 & 5 & 58,5 & 7,9 & 2 & 73,25 \\
\hline $\mathrm{SC}$ & 2 & 8,15 & 5 & 8,0 & 1,1 & 2 & 7,8 \\
\hline $\mathrm{SS}$ & 2 & 5,05 & 5 & 5,1 & 1,3 & 2 & 5,1 \\
\hline SS:SC & 2 & 62,2 & 5 & 63,9 & 16,9 & 2 & 66,5 \\
\hline $\mathrm{FC}$ & 2 & 3,9 & 5 & 6,9 & 2,6 & 2 & 3,95 \\
\hline 77 & 2 & 140,2 & 5 & 141,2 & 6,6 & 2 & 145,4 \\
\hline$<\mathrm{zm}^{\prime}$ & 2 & 123,3 & 5 & 132,0 & 6,6 & 2 & 131,0 \\
\hline 32 & 2 & 85,5 & 5 & 80,2 & 4,8 & 2 & 89,0 \\
\hline 72 & 2 & 86,5 & 5 & 88,6 & 2,3 & 2 & 89,5 \\
\hline 74 & 2 & 75,0 & 5 & 72,0 & 4,1 & 2 & 76,5 \\
\hline $75-1$ & 2 & 29,5 & 5 & 34,0 & 5,8 & 2 & 31,0 \\
\hline
\end{tabular}


M.A. Balabanova. Anthropological Composition of the Population of the Early Iron Age from the Lower Volga Region

Таблица 4. Средние размеры и указатели краниологических серий раннесарматского и среднесарматского времени

Table 4. Average sizes and indexes of craniological series of the Early Sarmatian and Middle Sarmatian times

\begin{tabular}{|c|c|c|c|c|c|c|c|c|c|c|c|c|}
\hline \multirow{3}{*}{$\begin{array}{c}\text { № по Мартину } \\
\text { и др. }\end{array}$} & \multicolumn{5}{|c|}{ Мужские серии } & \multicolumn{4}{|c|}{ Женские серии } & \multirow{2}{*}{\multicolumn{3}{|c|}{$\begin{array}{c}\text { Мужская серия } \\
\text { I-2-я пол. II в. н.э. }\end{array}$}} \\
\hline & \multicolumn{2}{|c|}{ IV-III вв. до н.э. } & \multicolumn{3}{|c|}{ II-I вв. До н.э. } & \multirow{2}{*}{$\begin{array}{c}\text { IV-III вв. до н.э. } \\
\text { XVI-20/2 } \\
\end{array}$} & \multicolumn{3}{|c|}{ II-I вв. до н.э. } & & & \\
\hline & $\mathrm{n}$ & $\mathrm{X}$ & $\mathrm{n}$ & $\mathrm{X}$ & $\mathrm{s}$ & & $\mathrm{n}$ & $\mathrm{X}$ & $\mathrm{s}$ & $\mathrm{n}$ & $\mathrm{X}$ & $\mathrm{s}$ \\
\hline 1 & 2 & 191,5 & 13 & 179,3 & 4,5 & 166 & 11 & 178,1 & 6,5 & 3 & 187,0 & 5,3 \\
\hline 8 & 2 & 141,0 & 13 & 147,4 & 6,4 & 145 & 12 & 141,7 & 5,2 & 3 & 143,7 & 2,3 \\
\hline $8: 1$ & 2 & 73,6 & 13 & 82,3 & 4,6 & 87,3 & 11 & 79,2 & 4,5 & 3 & 76,8 & 2,1 \\
\hline 17 & 1 & 136,0 & 13 & 131,1 & 5,8 & 129 & 11 & 128,3 & 4,6 & 3 & 138,7 & 9,3 \\
\hline $17: 1$ & 1 & 70,5 & 13 & 73,1 & 2,7 & 77,7 & 10 & 72,3 & 3,2 & 3 & 74,1 & 2,8 \\
\hline $17: 8$ & 1 & 94,4 & 13 & 89,1 & 5,7 & 89 & 11 & 90,3 & & 3 & 96,5 & 6,2 \\
\hline OPB & 1 & 276,6 & 13 & 266,6 & 5,8 & 255,4 & 10 & 261,45 & 5,5 & 3 & 273,6 & 8,8 \\
\hline M2 & 2 & 270,05 & 13 & 264,2 & 11,6 & 240,7 & 11 & 250,9 & 10,3 & 3 & 268,7 & 9,9 \\
\hline M3 & 1 & 1889,9 & 13 & 1732,4 & 123,8 & 1552,5 & 10 & 1621,5 & 96,45 & 3 & 1865,6 & 190,8 \\
\hline 5 & 1 & 109 & 13 & 100,5 & 5,1 & 98 & 11 & 100,0 & 6,9 & 3 & 106,0 & 1,7 \\
\hline 20 & 1 & 115 & 12 & 113,9 & 4,0 & 114 & 11 & 112,8 & 4,1 & 3 & 116,3 & 7,1 \\
\hline 9 & 1 & 97 & 13 & 98,3 & 3,0 & 98 & 12 & 97,7 & 4,7 & 3 & 97,0 & 6,1 \\
\hline УПИЛ & 1 & 135,85 & 13 & 132,6 & 5,6 & 133,7 & 12 & 134,0 & 4,0 & 3 & 134,0 & 3,6 \\
\hline 11 & 1 & 129 & 13 & 129,5 & 6,6 & 125 & 11 & 124,2 & 5,3 & 3 & 126,3 & 0,6 \\
\hline $28: 27$ & 1 & 105,7 & 12 & 91,0 & 5,6 & & 10 & 94,7 & 6,0 & 3 & 102,2 & 4,0 \\
\hline 45 & 2 & 133,5 & 13 & 135,8 & 7,3 & 126 & 11 & 129,3 & 4,2 & 3 & 135,7 & 2,5 \\
\hline 40 & 1 & 104 & 12 & 95,6 & 6,4 & 93 & 11 & 97,4 & 7,1 & 3 & 101 & 3,6 \\
\hline $40: 5$ & 1 & 95,4 & 12 & 94,8 & 4,0 & 94,9 & 11 & 97,4 & 4,7 & 3 & 95,3 & 3,4 \\
\hline 48 & 1 & 76,5 & 13 & 68,4 & 6,2 & 64 & 12 & 68,25 & 2,6 & 3 & 71,7 & 5,5 \\
\hline 43 & 2 & 112 & 13 & 108,2 & 3,5 & 102 & 12 & 105,6 & 5,1 & 3 & 112,3 & 7,5 \\
\hline 46 & 2 & 92 & 13 & 95,6 & 4,6 & 91 & 11 & 91,1 & 5,2 & 3 & 96,7 & 0,6 \\
\hline 54 & 2 & 23,5 & 13 & 25,0 & 1,5 & 22,5 & 12 & 24,0 & 1,8 & 3 & 24,0 & 1,0 \\
\hline 55 & 2 & 52 & 13 & 48,8 & 3,8 & 47 & 12 & 48,6 & 1,8 & 3 & 50,3 & 2,3 \\
\hline $54: 55$ & 2 & 45,5 & 13 & 51,7 & 5,3 & 47,9 & 12 & 50,0 & 3,4 & 3 & 47,6 & 1,2 \\
\hline 51 & 1 & 44 & 13 & 43,9 & 2,5 & 38 & 11 & 43,4 & 2,3 & 3 & 45,7 & 1,2 \\
\hline 52 & 2 & 32,5 & 13 & 32,5 & 2,1 & 29 & 12 & 34,0 & 2,6 & 3 & 32,7 & 1,3 \\
\hline $52: 51$ & 1 & 73,9 & 13 & 74,3 & 5,6 & 75 & 11 & 77,8 & 5,8 & 3 & 71,7 & 4,5 \\
\hline $\mathrm{DC}$ & 1 & 20,4 & 11 & 21,3 & 1,5 & 20,2 & 12 & 20,2 & 2,1 & 3 & 19,7 & 0,4 \\
\hline DS & 1 & 14,9 & 10 & 13,8 & 1,5 & 12,6 & 12 & 12,3 & 0,8 & 3 & 13,5 & 0,4 \\
\hline DS:DC & 1 & 73,0 & 10 & 65,2 & 5,8 & 62,4 & 12 & 61,4 & 8,7 & 3 & 68,4 & 2,0 \\
\hline $\mathrm{SC}$ & 2 & 10,05 & 12 & 8,4 & 1,4 & 9,3 & 12 & 8,0 & 1,1 & 3 & 7,3 & 1,6 \\
\hline $\mathrm{SS}$ & 2 & 5,7 & 10 & 4,3 & 0,8 & 5,1 & 12 & 4,2 & 0,9 & 3 & 4,0 & 1,3 \\
\hline SS:SC & 2 & 56,9 & 10 & 52,0 & 13,9 & 54,8 & 12 & 52,8 & 10,8 & 3 & 53,9 & 8,8 \\
\hline $\mathrm{FC}$ & 2 & 3,5 & 11 & 5,5 & 1,8 & 5,5 & 12 & 5,1 & 1,7 & 3 & 5,0 & 0,3 \\
\hline 77 & 2 & 142,25 & 13 & 139,0 & 4,8 & 139,6 & 12 & 140,45 & 5,6 & 3 & 139,2 & 2,0 \\
\hline$<\mathrm{zm}^{\prime}$ & 2 & 121,65 & 13 & 131,8 & 4,6 & 124,7 & 11 & 130,9 & 4,9 & 3 & 128,0 & 1,6 \\
\hline 32 & 1 & 82 & 12 & 85,9 & 2,9 & 82 & 11 & 85,8 & 5,1 & 3 & 86,3 & 9,5 \\
\hline 72 & 1 & 87 & 12 & 89,8 & 1,9 & 93 & 11 & 88,2 & 3,5 & 3 & 89,0 & 1,0 \\
\hline 74 & 1 & 73 & 12 & 75,0 & 4,9 & 93 & 11 & 73,4 & 6,2 & 3 & 77,0 & 6,6 \\
\hline $75-1$ & 2 & 31 & 10 & 30,7 & 7,6 & 33 & 12 & 26,8 & 5,7 & 3 & 33,0 & 1,0 \\
\hline
\end{tabular}


M.А. Балабанова. Антропологический состав населения раннего железного века Нижнего Поволжья

Таблица 5. Средние размеры и указатели краниологических серий позднесарматского времени

Table 5. Average sizes and indexes of craniological series of the Late Sarmatian time

\begin{tabular}{|c|c|c|c|c|c|c|c|c|c|}
\hline \multirow{3}{*}{$\begin{array}{c}\text { № по Мартину } \\
\text { и др. }\end{array}$} & \multicolumn{6}{|c|}{ Мужские серии } & \multicolumn{3}{|c|}{ Женская серия } \\
\hline & \multicolumn{3}{|c|}{ Серия без деформации } & \multicolumn{6}{|c|}{ Серии со следами искусственной деформации } \\
\hline & $\mathrm{n}$ & $\mathrm{X}$ & $\mathrm{s}$ & $\mathrm{n}$ & $\mathrm{X}$ & $\mathrm{s}$ & \begin{tabular}{l|l}
$\mathrm{n}$ & \\
\end{tabular} & $\mathrm{X}$ & $\mathrm{s}$ \\
\hline 1 & 7 & 188,3 & 5,5 & 27 & 185,5 & 6,4 & 8 & 174.2 & 3.8 \\
\hline 8 & 7 & 141,3 & 6,8 & 27 & 138,6 & 3,8 & 8 & 138.0 & 3.5 \\
\hline $8: 1$ & 7 & 75,0 & 4,1 & 27 & 74,8 & 3,1 & 8 & 79.2 & 2.1 \\
\hline 17 & 8 & 133,8 & 5,5 & 27 & 140,3 & 7,2 & 8 & 134.9 & 8.5 \\
\hline $17: 1$ & 7 & 71,1 & 3,4 & 27 & 75,7 & 4,2 & 8 & 77.4 & 4.4 \\
\hline $17: 8$ & 7 & 94,8 & 6,2 & 27 & 101,3 & 5,5 & 8 & 97.8 & 4.4 \\
\hline OPB & 7 & 270,8 & 6,0 & 27 & 270,9 & 7,0 & 8 & 260.1 & 6.7 \\
\hline M2 & 7 & 266,0 & 14,3 & 27 & 257,2 & 12,3 & 8 & 240.5 & 9.3 \\
\hline M3 & 7 & 1778,3 & 122,2 & 27 & 1805,9 & 141,9 & 8 & 1622.9 & 135.5 \\
\hline 5 & 7 & 102,7 & 3,6 & 27 & 106,5 & 6,4 & 8 & 103.6 & 4.0 \\
\hline 20 & 7 & 115,7 & 5,3 & 25 & 121,7 & 4,5 & 8 & 117.8 & 7.3 \\
\hline 9 & 7 & 100,1 & 4,9 & 27 & 98,7 & 4,7 & 8 & 97.9 & 6.0 \\
\hline УПИЛ & 7 & 132,8 & 3,2 & 26 & 135,3 & 4,5 & 8 & 134.1 & 3.3 \\
\hline 11 & 7 & 129,7 & 5,8 & 25 & 127,6 & 4,5 & 8 & 126.2 & 3.9 \\
\hline $28: 27$ & 7 & 94,0 & 5,0 & 26 & 95,9 & 7,4 & 8 & 98.6 & 9.7 \\
\hline УИЛ & 7 & 132,6 & 4,5 & 26 & 143,4 & 4,5 & 8 & 146.0 & 5.1 \\
\hline УИЗ & 7 & 117,4 & 7,1 & 24 & 129,8 & 7,1 & 8 & 129.2 & 5.9 \\
\hline 45 & 7 & 137,0 & 6,2 & 27 & 136,7 & 5,7 & 8 & 132.4 & 5.2 \\
\hline 40 & 7 & 99,6 & 4,4 & 27 & 100,3 & 6,3 & 8 & 98.9 & 4.6 \\
\hline $40: 5$ & 7 & 97,0 & 3,5 & 27 & 94,4 & 5,2 & 8 & 94.5 & 4,7 \\
\hline 48 & 7 & 70,6 & 5,0 & 27 & 74,0 & 4,4 & 8 & 71.4 & 6.0 \\
\hline 43 & 7 & 111,3 & 5,8 & 26 & 109,3 & 3,8 & 8 & 106.9 & 3.3 \\
\hline 46 & 7 & 97,0 & 8,2 & 27 & 98,7 & 5,0 & 8 & 95.4 & 3.2 \\
\hline 54 & 7 & 26,6 & 3,0 & 27 & 25,4 & 1,6 & 8 & 24.9 & 1.3 \\
\hline 55 & 7 & 51,7 & 3,1 & 27 & 52,8 & 2,7 & 8 & 51.9 & 2.1 \\
\hline $54: 55$ & 7 & 51,4 & 5,4 & 27 & 48,1 & 2,5 & 8 & 48.0 & 3.2 \\
\hline 51 & 7 & 43,3 & 3,1 & 27 & 43,7 & 1,7 & 8 & 43.1 & 1.4 \\
\hline 52 & 8 & 32,6 & 1,6 & 27 & 34,6 & 2,0 & 8 & 35.8 & 2.0 \\
\hline $52: 51$ & 7 & 76,1 & 3,4 & 27 & 79,4 & 3,8 & 8 & 83.1 & 5.5 \\
\hline $\mathrm{DC}$ & 7 & 22,2 & 2,2 & 21 & 24,5 & 2,8 & 8 & 23.4 & 2.2 \\
\hline DS & 7 & 12,9 & 2,5 & 21 & 13,5 & 1,8 & 8 & 11.3 & 1.8 \\
\hline DS:DC & 7 & 57,0 & 7,1 & 21 & 55,7 & 9,4 & 8 & 48.2 & 7.0 \\
\hline $\mathrm{SC}$ & 7 & 8,8 & 1,7 & 23 & 9,6 & 2,6 & 8 & 9.2 & 1.9 \\
\hline SS & 7 & 5,8 & 1,6 & 22 & 4,8 & 1,1 & 8 & 3.6 & 1.4 \\
\hline SS:SC & 7 & 65,4 & 9,5 & 22 & 50,3 & 11,5 & 8 & 38.6 & 8.6 \\
\hline $\mathrm{FC}$ & 7 & 4,6 & 1,7 & 27 & 5,5 & 1,5 & 8 & 4.0 & 1.4 \\
\hline 77 & 7 & 139,2 & 4,3 & 26 & 139,6 & 5,1 & 8 & 140.5 & 3.0 \\
\hline$<\mathrm{zm}^{\prime}$ & 7 & 130,5 & 6,0 & 27 & 128,9 & 5,1 & 8 & 130.4 & 4.5 \\
\hline 32 & 7 & 82,1 & 5,7 & 24 & 77,6 & 4,2 & 8 & 78.5 & 5.2 \\
\hline 72 & 7 & 87,7 & 2,7 & 24 & 89,9 & 3,7 & 8 & 89.8 & 3.3 \\
\hline 74 & 7 & 74,7 & 5,5 & 24 & 77,9 & 7,1 & 8 & 76.5 & 6.4 \\
\hline $75-1$ & 7 & 31,4 & 5,8 & 22 & 31,2 & 5,2 & 8 & 21.6 & 4.8 \\
\hline
\end{tabular}


M.A. Balabanova. Anthropological Composition of the Population of the Early Iron Age from the Lower Volga Region

Таблица 6. Элементы главных компонент (ГК) для разнополых суммарных серий черепов из могильников Кривой Луки

Table 6. Elements of the main components (MC) for heterosexual total series of skulls from the cemeteries of Krivaya Luka

\begin{tabular}{|c|c|c|c|c|c|c|c|c|}
\hline \multirow{2}{*}{$\begin{array}{c}\text { № по Мартину } \\
\text { и др. }\end{array}$} & \multicolumn{4}{|c|}{ Мужчины } & \multicolumn{4}{|c|}{ Женщины } \\
\hline & I ГК & II ГК & III ГК & IV ГК & $\mathrm{I} \mathrm{\Gamma K}$ & II ГК & III ГК & IV ГК \\
\hline $8: 1$ & -0.252 & $\mathbf{0 . 5 0 7}$ & -0.145 & 0.170 & 0.331 & 0.230 & 0.474 & -0.312 \\
\hline $\mathrm{OPB}$ & 0.907 & 0.002 & -0.221 & -0.186 & -0.669 & 0.493 & -0.021 & 0.472 \\
\hline M2 & 0.668 & 0.283 & -0.356 & -0.180 & -0.430 & 0.622 & 0.160 & 0.452 \\
\hline M3 & 0.896 & 0.060 & -0.212 & -0.135 & -0.656 & 0.498 & 0.024 & 0.381 \\
\hline УПИЛ & 0.134 & 0.533 & 0.643 & -0.091 & -0.023 & 0.244 & 0.610 & -0.498 \\
\hline $28: 27$ & 0.529 & -0.200 & 0.232 & -0.261 & -0.310 & -0.136 & -0.180 & -0.308 \\
\hline 45 & 0.600 & 0.499 & 0.113 & -0.164 & -0.511 & 0.095 & 0.444 & 0.038 \\
\hline 48 & 0.706 & -0.369 & 0.372 & -0.038 & -0.483 & -0.219 & -0.096 & 0.245 \\
\hline $54: 55$ & -0.364 & 0.447 & -0.483 & -0.122 & 0.024 & 0.450 & -0.577 & -0.110 \\
\hline $52: 51$ & -0.116 & -0.493 & 0.607 & -0.025 & -0.362 & -0.387 & -0.046 & -0.458 \\
\hline MS:MC & 0.199 & 0.184 & -0.018 & $\mathbf{0 . 8 2 0}$ & $\mathbf{0 . 8 0 0}$ & 0.362 & -0.089 & 0.003 \\
\hline DS:DC & 0.168 & 0.298 & -0.150 & 0.764 & 0.821 & 0.400 & -0.075 & 0.115 \\
\hline SS:SC & 0.361 & 0.254 & 0.259 & 0.509 & 0.806 & 0.091 & -0.006 & 0.257 \\
\hline $\mathrm{FC}$ & -0.177 & 0.485 & 0.247 & -0.147 & 0.360 & 0.469 & 0.380 & 0.229 \\
\hline 77 & -0.159 & 0.567 & 0.440 & -0.315 & 0.127 & 0.411 & 0.145 & -0.619 \\
\hline$<\mathrm{zm}$ & -0.292 & 0.505 & 0.247 & -0.298 & -0.156 & 0.356 & 0.651 & -0.200 \\
\hline 72 & 0.039 & -0.135 & 0.258 & 0.279 & 0.136 & -0.541 & 0.562 & 0.386 \\
\hline 74 & 0.013 & -0.253 & 0.526 & 0.274 & 0.203 & -0.646 & 0.481 & 0.394 \\
\hline $75-1$ & 0.223 & 0.620 & 0.230 & 0.126 & 0.822 & -0.060 & -0.051 & 0.316 \\
\hline $\begin{array}{l}\text { Собственные } \\
\text { числа }\end{array}$ & 3.828 & 2.959 & 2.263 & 2.128 & 4.764 & 2.948 & 2.350 & 2.255 \\
\hline \% дисперсии & 20.148 & 15.575 & 11.911 & 11.201 & 25.074 & 15.514 & 12.369 & 11.869 \\
\hline
\end{tabular}


M.А. Балабанова. Антропологический состав населения раннего железного века Нижнего Поволжья
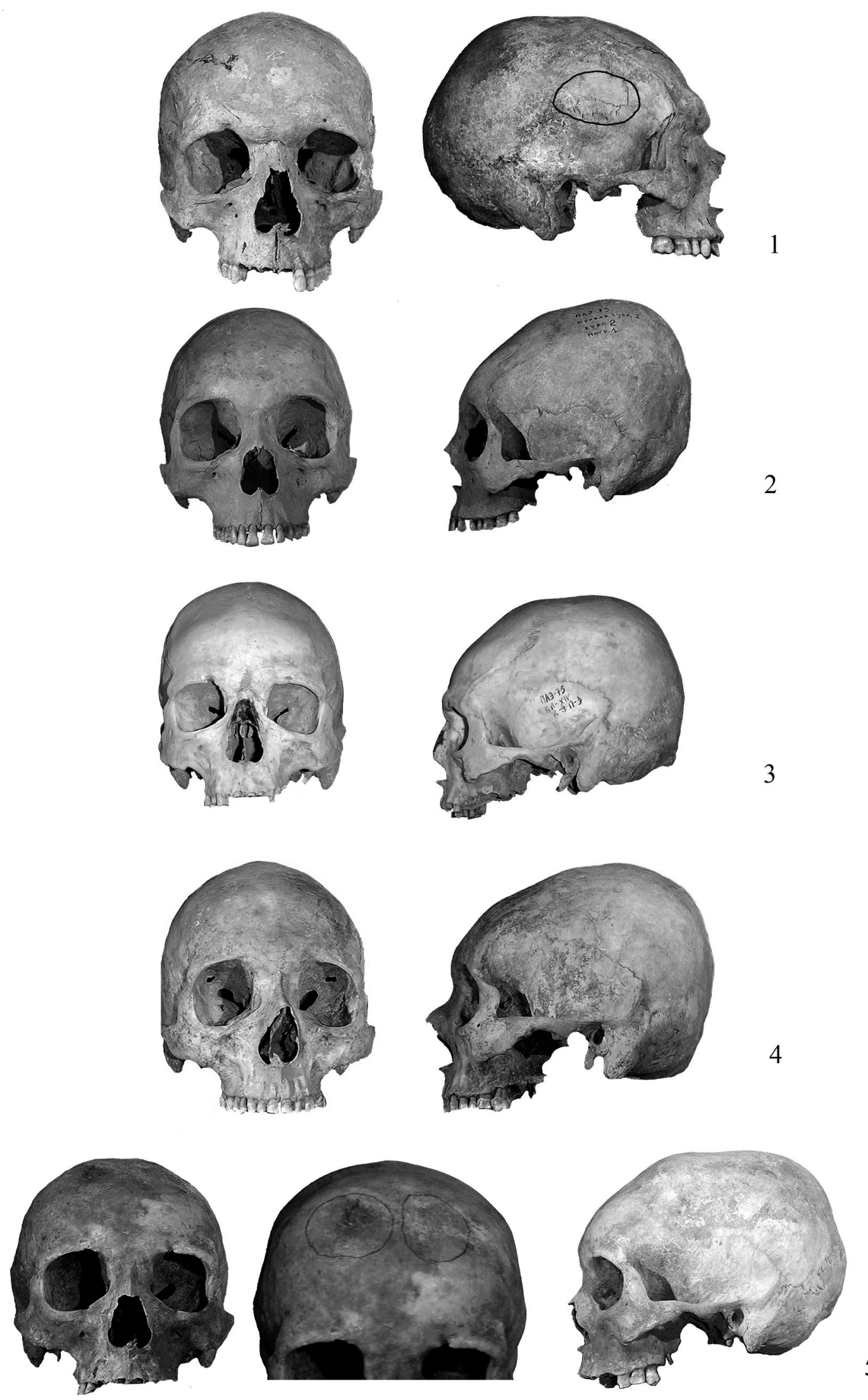

Рис. 1. Краниологические типы населения савроматского и позднесарматского времени из курганных групп Кривой Луки: 
1 - длинноголовый европеоидный комплекс на мужском черепе (18-20 лет) из погребения 3 кургана 1 группы XXXV (савроматское время); 2 - смешанный европеоидно-монголоидный комплекс и следы преднамеренной искусственной деформации головы на женском черепе (25-35 лет) из погребения 1 кургана 2 группы I (позднесарматское время); 3 - массивный длинноголовый тип и следы искусственной деформации на черепе мужчины (старше 50 лет) из погребения 3 кургана 9 группы XIV (позднесарматское время); 4 - субрахикранный комплекс с возможной монголоидной примесью и следами искусственной деформации на черепе мужчины (старше 50 лет) из погребения 1 кургана 16 группы XVI (позднесарматское время);

5 - субрахикранный комплекс с возможной монголоидной примесью и следами искусственной деформации на черепе женщины (45-55 лет) из погребения 1 кургана 39 группы XVII (позднесарматское время)

Fig. 1. Craniological types of the population of the Sauromat and Late Sarmatian times from the kurgan groups of Krivaya Luka:

1 - a long-headed Caucasian complex on a male skull (18-20 years old) from burial 3 of kurgan 1 of group XXXV (Sauromatian time); 2 - a mixed Caucasian-Mongoloid complex and traces of deliberate artificial head deformation on a female skull (25-35 years old) from burial 1 of kurgan 2 of group I (late Sarmatian time);

3 - massive long-headed type and traces of artificial deformation on the skull of a man (age 50) from burial 3 of kurgan 9 of group XIV (Late Sarmatian time); 4 - subrachicranial complex with a possible Mongoloid admixture and traces of artificial deformation on the skull of a man (age 50) from burial 1 of kurgan 16 of group XVI (late Sarmatian time); 5 - subrachicranial complex with a possible Mongoloid admixture and traces of artificial deformation on the skull of a woman (45-55 years old) from burial 1 of kurgan 39, group XVII (late Sarmatian time) 


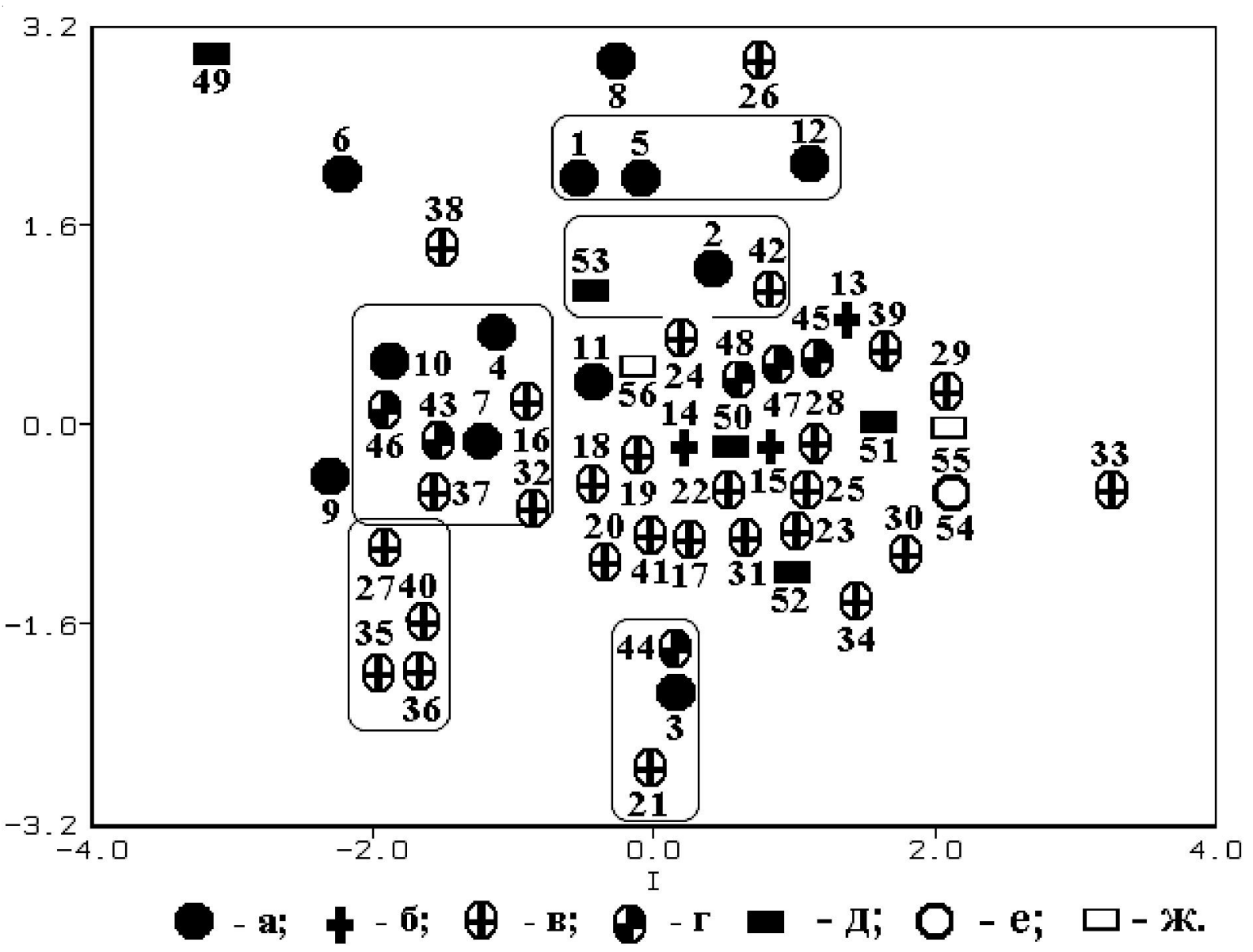

Рис. 2. Результат неметрического многомерного шкалирования и кластерного анализа матрицы внутригрупповых корреляций мужской суммарной серии из могильников Кривой Луки:

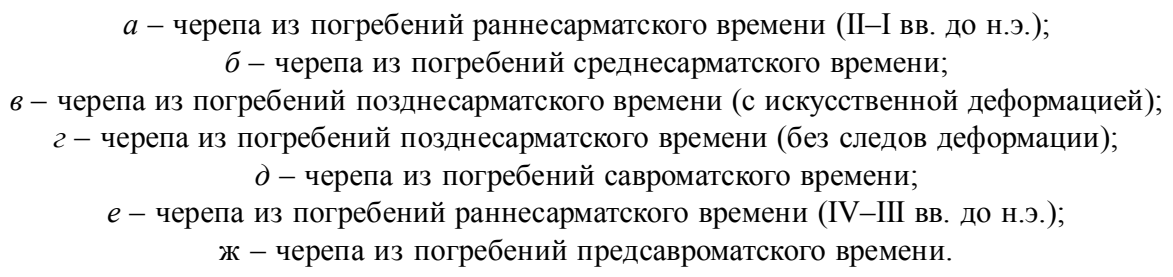

Черепа из погребений раннесарматского времени (II-I вв. до н.э.): 1 - I-1/1, костяк 1 ; 2 - I-1/1, костяк 2; 3 - II-2/8; 4 - III-1/26, костяк $1 ; 5$ - III- $1 / 28$, костяк $1 ; 6$ - III-1, костяк $2 ; 7$ - VIII-5/2, костяк $1 ; 8$ - VIII-5/7; 9 - XIV-16/1; 10 - XVI-1/33; $11-\mathrm{XXVIII-1/6;12-XXVIII-1/20.}$

Черепа из погребений среднесарматского времени: 13 - XVI-11/1; 14 - XVII-25/3; 15 - XXII-1/2. Черепа из погребений позднесарматского времени (со следами искусственной деформации): 16 - I-7/1; 17 - I-10/1; 18 - VI-3/1; 19 - VI-4/1; 20 - VI-10/1; 21 - VI-18/1; 22 - IX-5/2; 23 - XIV-9/3; 24 - XIV-10/1; 25 - XIV-14/1;26-XVI-1/1; 27 - XVI-12/1;28 - 13/1;29 - XVI-16/1; 30 - XVI-17/1; 31 - XVII-7/1; 32 - XVII-KM (?); 33 - XVII-9/1; 34 - XVII-13/1; 35 - 14/1; 36 - XVII-17/1; 37 - XVII-20/1; 38 - XVII-22/1; 39 - XVII-41/1; 40 - XVII-44/1; 41 - XVII-45/1; 42 - XVII-50/1.

Черепа из погребений позднесарматского времени (без деформации): 43 - I-5/1; 44 - VI-13/1; 45 - XIV-11/1; 46 - XVI-9/1; 47 - XVI-19/1; 48 - VII-2/1.

Черепа из погребений савроматского времени: 49 - XVII-19/2; 50 - XXXV-1/13; 51 - XXXV-1/3; 52 - III-1/5; 53 - XXVIII-1/18.

Черепа из погребений раннесарматского времени (IV-III вв. до н.э.): $54-\mathrm{XV}-2 / 8$.

Черепа из погребений предсавроматского времени: 55 - XXVIII-1/22; 56 - II-1/7 
Fig. 2. Result of non-metric multidimensional scaling and cluster analysis

of the matrix of intragroup correlations of the male summary series from the cemeteries of Krivaya Luka:

$a$ - skulls from burials of the early Sarmatian period (II-I centuries BC); $b$ - skulls from burials of the Middle Sarmatian period;

$c$ - skulls from burials of the Late Sarmatian period (with artificial deformation); $d$ - skulls from burials of the late Sarmatian period (without traces of deformation); $e$ - skulls from burials of the Sauromat time;

$f$ - skulls from burials of the early Sarmatian period (IV-III centuries BC); $g$ - skulls from burials of the pre-Sauromatian time.

Skulls from burials of the Early Sarmatian period (II-I centuries BC): 1 - I-1/1, bone 1; 2- I-1/1, cost 2; 3 - II-2/8; 4 - III-1/26, cost. $1 ; 5$ - III-1/28, cost $1 ; 6$ - III-1, cost $2 ; 7$ - VIII-5/2, cost $1 ; 8$ - VIII-5/7; 9 - XIV-16/1; 10 - XVI-1/33; 11 - XXVIII-1/6; 12 - XXVIII-1/20.

Skulls from burials of the Middle Sarmatian period: 13 - XVI-11/1; 14 - XVII-25/3; 15 - XXII-1/2.

Skulls from burials of the Late Sarmatian period (with traces of artificial deformation): 16 - I-7/1; 17 - I-10/1; 18 - VI-3/1; 19 - VI-4/1; 20 - VI-10/1; 21 - VI-18/1; 22 - IX-5/2; 23 - XIV-9/3; 24 - XIV-10/1; 25 - XIV-14/1; 26 - XVI-1/1; 27 - XVI-12/1; 28 - 13/1; 29 - XVI-16/1; 30 - XVI-17/1; 31 - XVII-7/1; 32 - XVII-KM (?); 33 - XVII-9/1; 34 - XVII-13/1; 35 - 14/1; 36 - XVII-17/1; 37 - XVII-20/1; 38 - XVII-22/1; 39 - XVII-41/1; 40 - XVII-44/1; 41 - XVII-45/1; 42 - XVII-50/1.

Skulls from burials of the Late Sarmatian period (without deformation): 43 - I-5/1; 44 - VI-13/1; 45 - XIV-11/1; 46 - XVI-9/1; 47 - XVI-19/1; 48 - VII-2/1.

Skulls from burials of the Sauromatian time: 49 - XVII-19/2; 50 - XXXV-1/13; $51-\mathrm{XXXV-1/3}$; 52 - III-1/5; 53 - XXVIII-1/18.

Skulls from burials of the Early Sarmatian time (IV-III centuries BC): $54-\mathrm{XV}-2 / 8$. Skulls from burials of the pre-Sauromatian period: 55 - XXVIII-1/22; 56 - II-1/7 


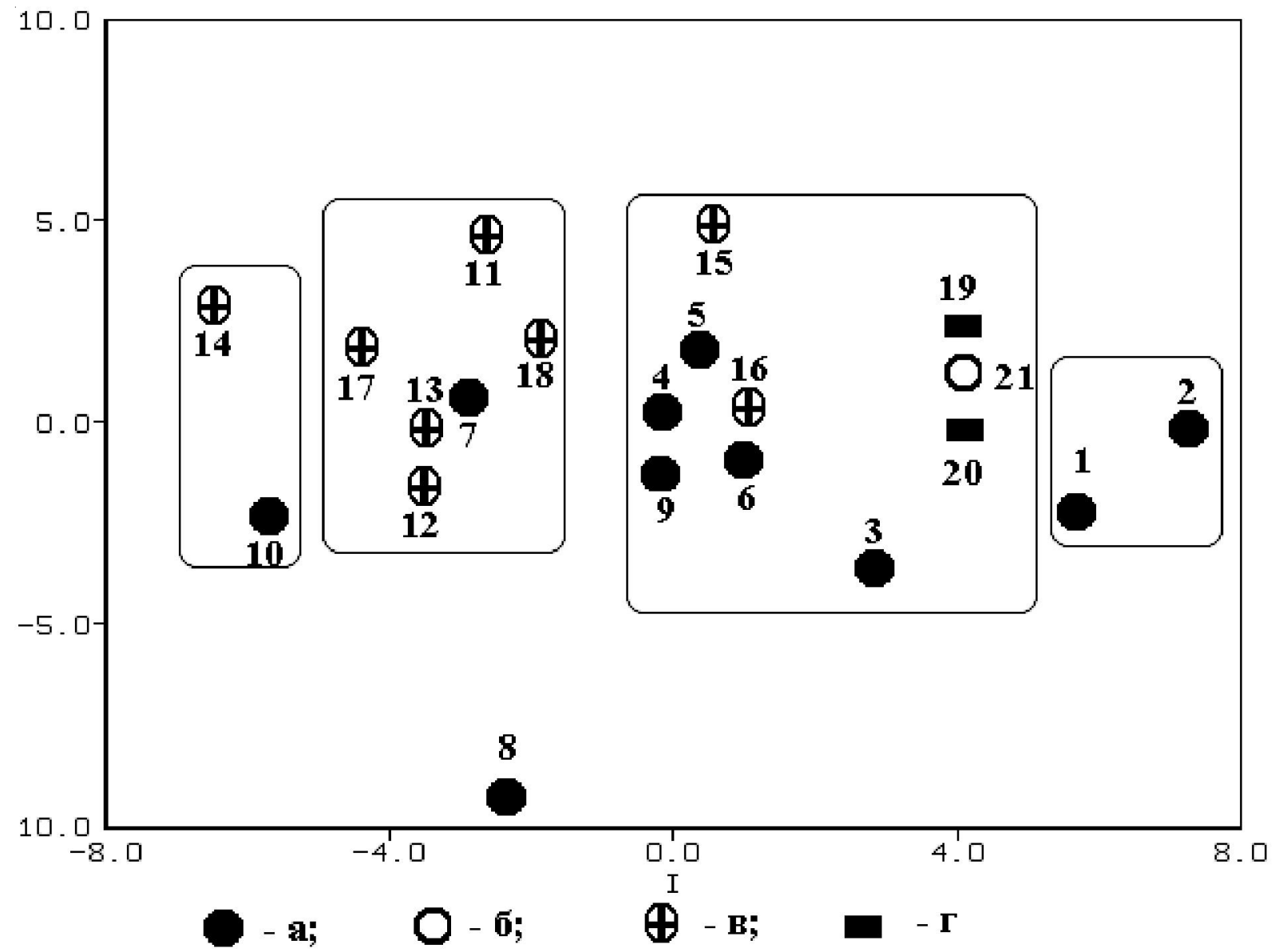

Рис. 3. Результат неметрического многомерного шкалирования и кластерного анализа матрицы внутригрупповых корреляций мужской суммарной серии из могильников Кривой Луки:

$a$ - черепа из погребений раннесарматского времени (II-I вв. до н.э.);

$\sigma$ - черепа из погребений раннесарматского времени (IV-III вв. до н.э.); в - черепа из погребений позднесарматского времени (с искусственной деформацией); 2 - черепа из погребений савроматского времени.

Черепа из погребений раннесарматского времени (II-I вв. до н.э.): 1 - IV-1/10; 2 - VI-1/15; 3 - VIII-2/14; 4 - VIII-4/4; 5 - IX-2/15; 6 - XII-1/6; 7 - II- $1 / 4 ; 8$ - II-2/2; 9 - IX-2/10; 10 - XVI-1/30.

Черепа из погребений позднесарматского времени (со следами искусственной деформации): 11 - I-2/1; 12 - I-9/1; 13 - XVII-8/1; 14 - XVII-12/1; 15 - XVII-30/1; 16 - XVII-32/1; 17 - XVII-39/1; 18 - XVII-42.

Черепа из погребений савроматского времени: 19 - XXI-4/2; 20 - XXI-1/6.

Черепа из погребений раннесарматского времени (IV-III вв. до н.э.): 21 - XVI-10/2

Fig. 3. Result of non-metric multidimensional scaling and cluster analysis of the matrix of intragroup correlations of the female summary series from the cemeteries of Krivaya Luka:

$a$ - skulls from burials of the early Sarmatian period (II-I centuries BC);

$b$ - skulls from burials of the early Sarmatian period (IV-III centuries BC);

$c$ - skulls from burials of the Late Sarmatian period (with artificial deformation); $d$ - skulls from burials of the Sauromatian time.

Skulls from burials of the early Sarmatian period (II-I centuries BC): 1 - IV-1/10; 2 - VI-1/15; 3 - VIII-2/14;

4 - VIII-4/4; 5 - IX-2/15; 6 - XII-1/6; 7 - II- $1 / 4 ; 8$ - II-2/2; 9 - IX-2/10; 10 - XVI-1/30.

Skulls from burials of the Late Sarmatian period (with traces of artificial deformation): 11 - I-2/1; 12 - I-9/1; 13 - XVII-8/1; 14 - XVII-12/1; 15 - XVII-30/1; 16 - XVII-32/1; 17 - XVII-39/1; 18 - XVII-42.

Skulls from burials of the Sauromat period: 19 - XXI-4/2; 20 - XXI-1/6.

Skulls from burials of the Early Sarmatian period (IV-III centuries BC): 21 - XVI-10/2 


\section{СПИСОК ЛИТЕРАТУРЫ}

Алексеев В. П., Дебец Г. Ф., 1964. Краниометрия. Методика антропологических исследований. М. : Наука. 127 с.

Балабанова М. А., 1998. Методика палеоантропологических исследований : учеб.-метод. пособие. Волгоград : Изд-во ВолГУ. 80 с.

Балабанова М. А., 1999. Антропология сарматских погребальных памятников Нижнего Поволжья IV-III вв. до н.э. // Нижневолжский археологический вестник. Вып. 2. С. 54-72.

Балабанова М. А., 2000. Антропология древнего населения Южного Приуралья и Нижнего Поволжья. Ранний железный век. М. : Наука. 133 с.

Балабанова М. А., 2005. Антропология населения Восточно-европейских степей в предскифское время // II Городцовские чтения : материалы науч. конф., посвящ. 100-летию деятельности В.А. Городцова в ГИМ. Труды ГИМ. Вып. 145. М. : ГИМ. С. 156-170.

Балабанова М. А., 2007. Половозрастная структура и краниология населения второй половины II - IV веков нашей эры (по материалам могильников Астраханского Правобережья) // Вестник антропологии. Научный альманах. Вып. 15, ч. II. С. 314-325.

Балабанова М. А., 2013. Позднесарматское население Нижнего Поволжья и сопредельных территорий в антропологическом контексте раннего железа и раннего средневековья : автореф. дис. ... д-ра ист. наук. M. 65 c.

Беневоленская Ю. Д., 1980. Мировое распределение затылочно-теменного указателя // Современные проблемы и новые методы в антропологии. Л. : Наука. С. 70-90.

Дворниченко В. В., Демиденко С. В., 2017. Погребения савроматского времени из курганной группы Кривая Лука XI // Краткие сообщения института археологии. Вып. 249, ч. 1. С. 187-201.

Дворниченко В. В., Малиновская Н. В., Федоров-Давыдов Г. А., 1977. Раскопки курганов в урочище Кривая Лука // Древности Астраханского края. Труды Поволжской археологической экспедиции. Вып. 4. М. : Наука. 194 с.

Дворниченко В. В., Федоров-Давыдов Г. А., 1989. Памятники сарматской аристократии в Нижнем Поволжье // Сокровища сарматских вождей и древние города Поволжья. М. : Наука. С. 5-13.

Дерябин В. Е., 1983. Многомерная биометрия для антропологов. М. : Изд-во МГУ. 227 с.

Дерябин В. Е., 1998. О методиках многомерного таксономического анализа в антропологии // Вестник антропологии. Научный альманах. Вып. 4. С. 30-68.

Казарницкий А. А., 2010. Краниология населения лолинской культуры // Вестник археологии, антропологии и этнографии. № 1 (12). С. 132-140.

Казарницкий А. А., 2012. Население азово-каспийских степей в эпоху бронзы (антропологический очерк). СПб. : Наука. 264 c.

Казарницкий А. А., 2013а. Краниология населения бабинской культуры // Вестник археологии, антропологии и этнографии. №2 2 (21). С. 70-78.

Казарницкий А. А., 2013б. Краниология носителей посткатакомбных культур // Проблемы периодизации и хронологии в археологии эпохи раннего металла Восточной Европы : материалы темат. науч. конф. СПб. : Скифия-принт. С. 54-60.

Казарницкий А.А., 2020. Миграции посткатакомбного населения: возможности реконструкции по краниологическим данным // Stratum plus. № 2. С. 275-289.

Круглов Е. В., 2001. Погребальный обряд огузов Северного Прикаспия 2-й пол. IX - 1-й пол. XI в. // Степи Европы в эпоху средневековья. Т. 2. Хазарское время. Донецк : Изд-во ДонНУ. С. 395-446.

Мимоход Р. А., 2005. Блок посткатакомбных культурных образований (постановка проблемы) // Проблеми дослідження пам яток археологіп Східноп Украпни. Луганськ. С. 70-74.

Мимоход Р. А., 2014. Посткатакомбный период в Нижнем Поволжье: от криволукской к Волго-Донской бабинской культуре // Краткие сообщения института археологии. Вып. 232. С. 100-119.

Мимоход Р. А., 2019. Теория оптимального кризиса: экология и адаптация // Природа. № 1. С. 43-49.

Федоров-Давыдов Г. А., 1984. Погребения хазарского времени из урочища «Кривая Лука» в Нижнем Поволжье // Проблемы археологии степей Евразии. Советско-венгерский сборник. Кемерово : Изд-во КемГУ. C. 80-94. 
Федоров-Давыдов Г. А., Дворниченко В. В., Паромов Я. М., 1979. Отчет о раскопках курганов в зоне строительства I очереди Калмыцко-Астраханской рисовой оросительной системы в Черноярском р-не Астраханской обл. в 1979 г. // Архив Астраханского Историко-архитектурного музеязаповедника.

Хохлов А. А., Мимоход Р. А., 2008. Краниология населения степного Предкавказья и Поволжья в посткатакомбное время // Вестник антропологии. Вып. 16. С. 44-70.

Шевченко А. В., 1980. Палеоантропология Северо-Западного Прикаспия в эпоху бронзы : автореф. дис. ... канд. ист. наук. Москва. 23 с.

Шевченко А. В., 1986. Антропология населения южнорусских степей в эпоху бронзы // Антропология современного и древнего населения Европейской части СССР. Л. : Наука. С. 121-215.

Яблонский Л. Т., 1980. Население средневековых городов Поволжья (по материалам мусульманских могильников) : автореф. дис. ... канд. ист. наук. М. 28 с.

Яблонский Л. Т., 2002. Антропологические данные к этногенезу народов Поволжья (по материалам Поволжской экспедиции) // Нижневолжский археологический вестник. Вып. 5. С. 24-46.

\section{REFERENCES}

Alekseev V.P., Debets G.F., 1964. Kraniometriya: Metodika antropologicheskikh issledovaniy [Craniometry: Technique of Anthropological Research]. Moscow, Nauka Publ. 127 p.

Balabanova M. A., 1998. Metodika paleoantropologicheskih issledovaniy: Uchebno-metodicheskoye posobiye [Methodology of paleoanthropological research: Manual]. Volgograd, VolSU. 80 p.

Balabanova M.A., 1999. Antropologiya sarmatskih pogrebal'nyh pamyatnikov Nizhnego Povolzh'ya IV-III vv. do n.e. [The Anthropological Analysis of the Lower Volga Sarmatian Materials Dating of the IV-III BC]. Nizhnevolzhskiy arkheologicheskiy vestnik [The Lower Volga Archaeological Bulleten], vol. 2, pp. 54-72.

Balabanova M.A., 2000. Antropologiya drevnego naseleniya Yuzhnogo Priuralya i Nizhnego Povolzhya. Ranniy zheleznyy vek [Anthropology of the Ancient Population of the Southern Urals and the Lower Volga Region. Early Iron Age]. Moscow, Nauka Publ. 133 p.

Balabanova M.A., 2005. Antropologiya naseleniya Vostochno-evropeyskih stepey v predskifskoe vremya [Anthropology of the Population of the East European Steppes in the Pre-Scythian Time]. II Gorodtsovskie chteniya. Materialy nauchnoy konferentsii, posvyashchennoy 100-letiyu deyatel'nosti V.A. Gorodtsova v GIM. Trudy Gosudarstvennogo Istoritcheskogo Muzeya [II Gorodtsovskie Readings. Materials of the Scientific Conference Dedicated to the $100^{\text {th }}$ Anniversary of V.A. Gorodtsov at the State Historical Museum. Proceedings of the State Historical Museum], iss. 145. Moscow, SHM, pp. 156-170.

Balabanova M.A., 2007. Polovozrastnaya struktura i kraniologiya naseleniya vtoroy poloviny II-IV vekov nashey ery (po materialam mogil'nikov Astrahanskogo Pravoberezh'ya) [Age-Sex Structure and Craniology of the Population in the Second Half of the $2^{\text {nd }}-4^{\text {th }}$ Centuries AD (Based on Materials from the Cemeteries of the Astrakhan Right Bank)]. Vestnik antropologii. Nauchnyy al'manah [Herald of Anthropology. Scientific Almanac], iss. 15 (II), pp. 314-325.

Balabanova M.A., 2013. Pozdnesarmatskoe naselenie Nizhnego Povolzh'ya i sopredel'nyh territoriy $v$ antropologicheskom kontekste rannego zheleza i rannego srednevekov'ya: avtoref. dis. ... doc. ist. nauk [Late Sarmatian Population of the Lower Volga Region and Adjacent Territories in the Anthropological Context of the Early Iron and Early Middle Ages. Doc. hist. sci. abs. diss.]. Moscow. 65 p.

Benevolenskaya Yu.D., 1980. Mirovoe raspredelenie zatylochno-temennogo ukazatelya [World Distribution of the Occipital-Parietal Index]. Sovremennye problemy i novye metody v antropologii [Modern Problems and New Methods in Anthropology]. Leningrad, Nauka Publ., pp. 70-90.

Dvornichenko V.V., Demidenko S.V., 2017. Pogrebeniya savromatskogo vremeni iz kurgannoy gruppy Krivaya Luka XI [Sauromaian Sites from the Krivaya Luka XI Kurgan Group]. Kratkie soobshcheniya Instituta Arheologii [Brief Communications of the Institute of Archaeology], iss. 249 (1), pp. 187-201.

Dvornichenko V.V., Malinovskaya N.V., Fedorov-Davydov G.A., 1977. Raskopki kurganov v urochishche Krivaya Luka [Excavations of Kurgans in the Urochische Krivaya Luka]. Drevnosti Asrahanskogo kraya. Trudy Povolzhskoy arheologicheskoy ekspeditsii [Antiquities of the Astrakhan Region. Proceedings of the Volga Archaeological Expedition], iss. 4. Moscow, Nauka Publ. 194 p. 
Dvornichenko V.V., Fedorov-Davydov G.A., 1989. Pamyatniki sarmatskoy aristokratii v Nizhnem Povolzh'e [Monuments of the Sarmatian Aristocracy in the Lower Volga Region]. Sokrovishcha sarmatskih vozhdey $i$ drevnie goroda Povolzh'ya [Treasures of the Sarmatian Leaders and Ancient Cities of the Volga Region]. Moscow, Nauka Publ., pp. 5-13.

Deryabin V.E., 1983. Mnogomernaya biometriya dlya antropologov [Multidimensional Biometrics for Anthropologists]. Moscow, MSU. 227p.

Deryabin V.E., 1998. O metodikah mnogomernogo taksonomicheskogo analiza v antropologii [On the Methods of Multidimensional Taxonomic Analysis in Anthropology]. Vestnik antropologii. Nauchnyy al'manah [Herald of Anthropology. Scientific Almanac], iss. 4, pp. 30-68.

Kazarnitskiy A.A., 2010. Kraniologiya naseleniya lolinskoy kul'tury [Craniology with Population of the Lolino Culture]. Vestnik arheologii, antropologii i etnografii [Bulletin of Archaeology, Anthropology and Ethnography], no. 1 (12), pp. 132-140.

Kazarnitskiy A.A., 2012. Naselenie azovo-kaspiyskih stepey v epohu bronzy (antropologicheskiy ocherk) [Population of the Azov-Caspian Steppes in the Bronze Age (Anthropological Essay)]. Saint-Petersburg, Nauka Publ. 264 p.

Kazarnitskiy A.A., 2013a. Kraniologiya naseleniya babinskoy kul'tury [Craniology with Population of the Babino Culture]. Vestnik arheologii, antropologii $i$ etnografii [Bulletin of Archaeology, Anthropology and Ethnography], no. 2 (21), pp. 70-78.

Kazarnitskiy A.A., 2013b. Kraniologiya nositeley postkatakombnyh kul'tur [Craniology of the Carriers of PostCatacomb Cultures]. Problemy periodizatsii i hronologii v arheologii epohi rannego metalla Vostochnoy Evropy. Materialy tematicheskoy nauchnoy konferentsii [Problems of Periodization and Chronology in the Archaeology of the Early Metal Era of Eastern Europe. Materials of the Thematic Scientific Conference]. Saint-Petersburg, Skifiya-print Publ., pp. 54-60.

Kazarnitskiy A.A., 2020. Migratsii postkatakombnogo naseleniya: vozmozhnosti rekonstruktsii po kraniologicheskim dannym [Migration of the Post-Catacomb Population: Possibilities for Reconstruction by Craniological Data]. Stratum plus, no. 2, pp. 275-289.

Kruglov E.V., 2001. Pogrebal'nyy obryad oguzov Severnogo Prikaspiya 2-y poloviny IX - 1-y poloviny XI v. [Funeral Rite of the Oguzes of the Northern Caspian Region of the $2^{\text {nd }}$ half of the $9^{\text {th }}-1^{\text {st }}$ half of the $11^{\text {th }}$ century]. Stepi Evropy v epohu srednevekov'ya. Hazarskoe vremya [Steppes of Europe in the Middle Ages. Khazarian Time], vol. 2. Donetsk, DNU, pp. 395-446.

Mimokhod R.A., 2005. Blok postkatakombnyh kul'turnyh obrazovaniy (postanovka problemy) [Bloc of Post Catacomb Cultural Communities (Problem Posing)]. Problemy doslidzhennya pamyatok arheologin Skhidnon Ukranni [Research Problems of the Archaeological Sites of the Eastern Ukraine]. Lugansk, pp. 70-74.

Mimokhod R.A., 2014. Postkatakombnyy period v Nizhnem Povolzh'e: ot krivolukskoy k Volgo-Donskoy babinskoy kul'ture [Post-catacomb Period in the Lower Volga Region: from the Krivaya Luka Cultural Group to the VolgaDon Babino Culture]. Kratkie soobshcheniya Instituta Arheologii [Brief Communications of the Institute of Archaeology], iss. 232, pp. 100-119.

Mimokhod R.A., 2019. Teoriya optimal'nogo krizisa: ekologiya i adaptaciya [Theory of Optimum Crisis: Ecology and Adaptation]. Priroda [Nature], no. 1, pp. 43-49.

Fedorov-Davydov G.A., 1984. Pogrebeniya hazarskogo vremeni iz urochishcha «Krivaya Luka» v Nizhnem Povolzh’e [Burials of the Khazarian Period from the Krivaya Luka Tract in the Lower Volga Region]. Problemy arheologii stepey Evrazii. Sovetsko-vengerskiy sbornik [Problems of Archaeology of the Eurasian Steppes. SovietHungarian Collection]. Kemerovo, KSU, pp. 80-94.

Fedorov-Davydov G.A., Dvornichenko V.V., Paromov Ya.M., 1979. Otchet o raskopkah kurganov v zone stroitel'stva I ocheredi Kalmycko-Astrahanskoy risovoy orositel'noy sistemy v Chernoyarskom r-ne Astrahanskoy obl. v 1979 g. Arhiv Astrakhan Historical and Architectural Museum-Reserve.

Khohlov A.A., Mimokhod R.A., 2008. Kraniologiya naseleniya stepnogo Predkavkaz’ya i Povolzh'ya v postkatakombnoe vremya [Craniology of the Population of Steppe Caucasus and Volga Region Post-Catacomb Period]. Vestnik antropologii [Bulletin of Anthropology], iss. 16, pp. 44-70.

Shevchenko A.V., 1980. Paleoantropologiya Severo-Zapadnogo Prikaspiya v epohu bronzy: avtoref. dis. ... kand. ist. nauk [Paleoanthropology of the North-Western Caspian Sea in the Bronze Age. Cand. hist. sci. abs. diss.]. Moscow. 23 p. 
М.А. Балабанова. Антропологический состав населения раннего железного века Нижнего Поволжья

Shevchenko A.V., 1986. Antropologiya naseleniya yuzhnorusskih stepey v epohu bronzy [Anthropology of the Population of the Southern Russian Steppes in the Bronze Age]. Antropologiya sovremennogo $i$ drevnego naseleniya Evropeyskoy chasti SSSR [Anthropology of the Modern and Ancient Population of the European Part of the USSR]. Leningrad, Nauka Publ., pp. 121-215.

Yablonsky L.T., 1980. Naselenie srednevekovyh gorodov Povolzh'ya (po materialam musul'manskih mogil'nikov): avtoref. dis. ... kand. ist. nauk [Population of medieval cities of the Volga region (based on the materials of Muslim burial grounds). Cand. hist. sci. abs. diss.]. Moscow. 28p.

Yablonskiy L.T., 2002. Antropologicheskie dannye k etnogenezu narodov Povolzh'ya (po materialam Povolzhskoy ekspeditsii) [Anthropological Data on the Ethnogenesis of Peoples Inhabiting the Volga Area (On the Materials Obtained by the Povolzhskaya Expedition)]. Nizhnevolzhskiy arheologicheskiy vestnik [The Lower Volga Archaeological Bulletin], iss. 5, pp. 24-46.

\section{Information About the Author}

Mariya A. Balabanova, Doctor of Sciences (History), Professor, Department of Russian and Foreign History and Archaeology, Volgograd State University, Prosp. Universitetsky, 100, 400062 Volgograd, Russian Federation, mary.balabanova@volsu.ru, https://orcid.org/0000-0002-1565-474X

\section{Информация об авторе}

Мария Афанасьевна Балабанова, доктор исторических наук, профессор кафедры отечественной и зарубежной истории, археологии, Волгоградский государственный университет, просп. Университетский, 100, 400062 г. Волгоград, Российская Федерация, mary.balabanova@volsu.ru, https://orcid.org/0000-0002-1565-474X 